\title{
Chemical-induced contact allergy: from mechanistic understanding to risk prevention
}

\author{
Emanuela Corsini ${ }^{1} \cdot$ Ayşe Başak Engin ${ }^{2} \cdot$ Monica Neagu $^{3} \cdot$ Valentina Galbiati $^{1} \cdot$ Dragana Nikitovic $^{4}$. \\ George Tzanakakis ${ }^{4} \cdot$ Aristidis M. Tsatsakis $^{5}$
}

Received: 4 June 2018 / Accepted: 2 August 2018 / Published online: 10 August 2018

(c) Springer-Verlag GmbH Germany, part of Springer Nature 2018

\begin{abstract}
Chemical allergens are small molecules able to form a sensitizing complex once they bound to proteins. One of the most frequent manifestations of chemical allergy is contact hypersensitivity, which can have serious impact on quality of life. Allergic contact dermatitis is a predominantly CD8 + T cell-mediated immune disease, resulting in erythema and eczema. Chemical allergy is of considerable importance to the toxicologist, who has the responsibility of identifying and characterizing the allergenic potential of chemicals, and estimating the risk they pose to human health. This review aimed at exploring the phenomena of chemical-induced contact allergy starting from a mechanistic understanding, immunoregulatory mechanisms, passing through the potency of contract allergen until the hazard identification, pointing out the in vitro models for assessing contact allergen-induced cell activation and the risk prevention.
\end{abstract}

Keywords Allergic contact dermatitis $\cdot$ Potency $\cdot$ Contact allergens $\cdot$ In vitro methods

\section{Introduction}

Allergic contact dermatitis (ACD) is a cell-mediated immune response to small molecular weight chemicals that contact and penetrate the skin, resulting in erythema and eczema (Esser et al. 2012). Typically, the acquisition of contact allergy is accomplished in two temporally distinct phases: the sensitization or induction phase and the subsequent elicitation or challenge phase of the immune system. There are varieties of characteristics that determine whether

Valentina Galbiati

valentina.galbiati@unimi.it

1 Laboratory of Toxicology, Department of Environmental and Political Sciences, Università degli Studi di Milano, Via Balzaretti 9, 20133 Milan, Italy

2 Gazi Üniversitesi, Eczacılık Fakültesi, Toksikoloji, Hipodrom, 06330 Ankara, Turkey

3 Immunology Department, "Victor Babes" National Institute of Pathology, 99-101 Splaiul Independentei, 050096 Bucharest, Romania

4 Department of Histology-Embryology, School of Medicine, University of Crete, Heraklion, Greece

5 Department of Forensic Sciences and Toxicology, University of Crete, Heraklion, Greece a chemical can function as a contact sensitizer: (1) ability to penetrate the skin, (2) reactivity with carrier endogenous protein to form a complete antigen, (3) epidermal and dermal inflammation, (4) dendritic cell activation, migration to lymph nodes and recognition as antigenic by $\mathrm{T}$ cells.

$\mathrm{ACD}$ is a common phenomenon and epidemiological studies suggest that it affects up to $20 \%$ of the population (Koppes et al. 2017). Prior to marketing, manufacturers have to test pesticides, cosmetics, household cleaners, and other chemicals to identify the compounds that have the potential to cause allergic contact dermatitis. There are currently more than 4000 substances identified as contact allergens, and of the chemicals registered at ECHA, approximately $30 \%$ of them were classified as allergens (hazard). Regulatory authorities worldwide require testing for ACD and appropriate hazard labeling to minimize exposures and properly communicate the danger, and toxicologists have the responsibility of identifying and characterizing the skin sensitization potential of chemicals and estimating the risk they pose to human health.

This review aims to provide the state of the art in the field of skin sensitization from mechanistic understanding to risk assessment, with emphasis on non-animal test methods that can identify skin sensitizers. It is anticipated that the collected information will aid in selecting models 
for general screening and quantitative risk assessment for topical applied compounds and products. Understanding the mechanistic aspects involved in sensitization by chemicals is central to develop relevant preventive strategies.

\section{Understanding contact allergy}

$\mathrm{ACD}$ is a common skin diseases associated with severe and long-lasting health problems (Koppes et al. 2017). ACD develops in two phases, the sensitization phase leading to the priming of hapten-specific CD8 $+\mathrm{T}$ cells and the elicitation phase occurring after challenge and leading to the development of skin inflammation. In the following paragraph, the mechanisms underlying the acquisition of skin sensitization are described in detail.

\section{Induction phase of ADC}

Generally, humans become allergic after several repeated sub-threshold exposures to insulting substance that do not initially induce clinical signs, but which subsequently in susceptible individuals elicits an inappropriate immune response that results in allergic contact dermatitis (Stratum corneum et al. 2012). Many factors contribute to whether sensitization occurs and the nature and magnitude of the immune response, e.g. the time and severity of the clinical manifestation of contact allergy is dependent on the genetic background of the host and on the concentration of allergen during the induction phase (Friedmann and Pickard 2014). The adverse outcome pathway for skin sensitization provides a clear explanation of the sequence of events and their relationship, from haptenization to the clinical manifestation of allergic contact dermatitis (OECD 2014). Skin sensitization is a complex process that starts with the transdermal absorption of the chemical. The majority of allergens able to cross the stratum corneum are too small to be recognized by $\mathrm{T}$ cells, and this activity depends on their potential to establish stable covalent binding with endogenous proteins to form complete antigens (Nosbaum et al. 2009). The complex formation is related to the electrophilic reactivity and hydrophobicity of the allergen. In addition, many compounds are not allergenic themselves but are activated metabolically (pro-haptens) in the skin or activated via air oxidation (pre-haptens) before skin contact to turn into skin sensitizers (Karlberg et al. 2008). Pro-haptens are hydrophobic molecules and their activation by the host metabolism, provided mainly by the keratinocytes, the most abundant cells in the epidermis, (Oesch et al. 2018), turn them into reactive electrophile intermediary that can conjugate with host proteins to form a complete antigen (Aptula et al. 2007). Within the skin, cytochrome P450 (CYP)-dependent monooxygenase activities are low and other oxidative enzymes, like flavin monooxygenase, $\mathrm{COX}$ (cooxidation by prostaglandin synthase), are considered more relevant for the oxidative xenobiotic metabolism in the skin (Oesch et al. 2018). On the other hand, pre-haptens spontaneously oxidize to form hydroperoxides that can conjugate with host proteins (Lepoittevin 2006).

Once absorbed, simultaneously with the process of haptenization, and with a mechanism also linked to their electrophilicity, haptens trigger innate immune responses via pattern recognition receptors and production of endogenous danger signals, consequently causing sterile inflammation (Martin 2012). Several damage-associated molecular patterns (DAMPs) have been associated with contact dermatitis, including degradation of the extracellular matrix products, ATP, HGMB1, IL-1 $\alpha$ to mention some. Transient receptor potential (TRP) ion channels mediate acute inflammation, enhance skin sensitization following exogenous stimulation, and may contribute to allergic responses. TRP subfamily A, member 1 (TRPA1) and substance $P$ play central roles in the integration of immune and neuronal mechanisms leading to chronic inflammatory responses and pruritus associated with ACD (Liu et al. 2013).

Upon hapten exposure, allergen-induced inflammatory reaction leads to the migration of allergen-carrying DCs from the skin to regional lymph nodes, where they promote generation of allergen-specific $\mathrm{T}$ cells. These T-cells are the ultimate effector cells of the disease. ACD reactions are dependent on the priming of $\mathrm{T}$ cells during the sensitization phase. T-cell activation requires the combination of three distinct signals. The first signal involves the interaction of T-cell receptor (TCR) and the MHC/haptenated peptide complex. The two additional signals require co-stimulatory molecules and the secretion of cytokines by DCs. The absence of any of those signals may lead to anergy or to the death of the T cells (Vocanson et al. 2009). T lymphocytes are central elements in cell-mediated hypersensitivity. In this respect, $\mathrm{T}$ cells recognize haptens as structural entities that are covalently bound or anchored as self-peptide complexes in the binding grooves of major histocompatibility (MHC) antigens at the cell surface (Weltzien et al. 1996). MHC class I molecules expressed by dendritic cells are mandatory for the priming of hapten-specific $\mathrm{CD} 8+\mathrm{T}$ cells in the lymph nodes during the sensitization phase (Kolesaric et al. 1997; Krasteva et al. 1998). DCs are professional antigenpresenting cells. Keratinocyte-derived thymic stromal lymphopoietin (TSLP) activates DCs to induce naive T cell differentiation (Liu et al. 2007; Soumelis et al. 2002; Ebner et al. 2007). In contrast, receptor activator of NF- $\mathrm{KB}$ ligand (RANKL) overexpression in keratinocytes results in functional alterations of epidermal DCs and increases the number of peripheral CD $4+\mathrm{CD} 25+$ regulatory T cells (Tregs) cells (Loser et al. 2006). 
Neutrophils are also required for contact allergen-induced release of further neutrophil-attracting chemokines, migration of DCs to the draining lymph nodes, and priming of allergen-specific T cells. Neutrophils are critically involved in both the sensitization and elicitation phase of contact hypersensitivity (Weber et al. 2015).

\section{Toll-like receptors activation}

The first system of pattern recognition receptors (PRRs) and endogenous danger signals' recognition involves Toll-like receptors (TLRs), a class of membrane receptors that sense extracellular xenobiotics. TLRs recognize DAMPs, which are self-molecules that can be released during necrotic cell death. Cell death provokes inflammatory responses likely due to the release or production of endogenous ligands that activate resident immune cells (Sloane et al. 2010). TLR2 promotes interferon-gamma (IFN- $\gamma$ ) response to skinintroduced antigens (Jin et al. 2009). Major role in signaling in ACD is played by TLR2 and TLR4 and arises from their activation by extracellular DAMPs. Ligand activation of TLR4/TLR2 results in the expression of interleukins (ILs) IL-1 $\beta$, IL-6, IL-12, IL-18, and IL-23, tumor necrosis factor- $\alpha$ (TNF- $\alpha)$ and IFN- $\alpha$. These cytokines promote acquisition of sensitization and facilitate elicitation of contact allergy via multiple mechanisms, including the recruitment of CD4 + Th1 and Th17 cells (McFadden et al. 2013). TLR3 enhances antigen-independent skin inflammation in the elicitation phase of allergic contact dermatitis (Nakamura et al. 2015). TLRs are used by many cells of the innate immune system. Upon engagement, TLRs recruit one of the adaptor proteins, myeloid differentiation primary response gene 88 (MyD88), and via signaling through the protein, they initiate an immune response to contact allergen. MyD88 also involves in the signaling downstream of the IL-1 and IL-18 receptors (Klekotka et al. 2010).

A second system of PRRs and endogenous danger signals' recognition involves the formation of an intracellular complex of proteins termed the inflammasome (Martinon et al. 2009). Since one outcome of TLR signaling is the increased expression of mRNA for IL- $1 \beta$, IL-18 the TLR and inflammasome systems can work coordinately to induce the release of pro-inflammatory cytokines (Stratum corneum et al. 2009).

\section{Elicitation phase of ACD}

Re-exposure to the causative agent leads to the recruitment of effector T cells which then elicit the typical skin inflammatory reaction at the site of contact. Although DCs and effector $\mathrm{T}$ cells play a major role in the sensitization and elicitation phase of ACD, respectively, other cell types including keratinocytes, natural killer (NK) cells, mast cells, neutrophils, and B cells contribute to the pathogenesis of the disease (Freudenberg et al. 2009). Different types of Tregs are also crucial in the prevention of contact allergy or in the early termination of the reaction (Cavani et al. 2007). Indeed, during the sensitization phases, both CD4 + and CD8 + T cell precursors are activated in the draining lymph nodes by presentation of haptenated peptides by skin DCs (Saint-Mezard et al. 2004; Xu et al. 1996).

$\mathrm{T}$ cells in treated and distant skin as well as draining and distant $\mathrm{LN}$ contain common expanded memory $\mathrm{T}$ cell clones (resident memory T cells; TRM) that are not detectable before immunization. Memory T cells enter distant LN directly from blood through high endothelial venules rather than afferent lymphatics; thus, memory $\mathrm{T}$ cell clones in distant LN are considered as central memory T cells (TCM). TRM and TCM derive from common naïve T cell precursors. Presentation of contact allergens to naive T cells by activated DCs is a prerequisite for successful sensitization (Gaide et al. 2015). When the sensitized T lymphocytes are challenged by the same allergen, they infiltrate the skin and exert cytotoxic effects, secrete inflammatory mediators that trigger an eczematous skin reaction (Martin et al. 2011). Stimulated CD8 $+\mathrm{T}$ cells are the main mediators of direct cytotoxic action against keratinocytes. Further tissue damage is generated by $\mathrm{T}$ cell-released cytokines that exacerbate the inflammatory response by targeting resident skin cells. Thereby, ACD is regulated by specialized subsets of T lymphocytes (Girolomoni et al. 2004).

Upon proliferation, $\mathrm{T}$ cells migrate out of the lymph nodes and enter the blood circulation. They re-circulate between the lymphoid organs and the skin for screening for probable unknown compound challenges. Thus, through this process, re-exposure of sensitized individuals with the same hapten provokes the ACD within $24-72 \mathrm{~h}$ period. This phase is known as the elicitation or efferent phase of ACD. The sensitization phase of ACD lasts 10-15 days in man (Akiba et al. 2002).

ACD is controlled by the opposite functions of CD8 + effector T cells and CD4 + Tregs. In this respect, ACD can be considered as a breakdown of cutaneous immune tolerance to hapten-protein conjugates (SaintMezard et al. 2004). CD4 + Treg subsets are responsible for both the down-regulation of eczema in allergic patients and the prevention of priming to haptens in non-allergic individuals (Vocanson et al. 2009). On the other hand, before the onset of clinical and histological signs of skin inflammation, $\mathrm{CD} 8+\mathrm{T}$ cells rapidly recruit into the skin at the site of hapten challenge. This early CD8 $+\mathrm{T}$ cell recruitment is concomitant with the transient IFN- $\gamma$ mRNA expression suggesting local activation of effector cells and induction of keratinocyte apoptosis. Keratinocyte apoptosis gradually increases and reaches up to a maximum at the peak of the CHS response. Moreover, skin infiltration of CD4 + T cells 
occurs afterwards and coincides with the maximum peak of the CHS reaction. This event immediately triggers the resolution of skin inflammation (Akiba et al. 2002). Tregs and the IL-10 secreting type I Tregs are potently important in the control (resolution) of allergic contact dermatitis (Gober and Gaspari 2008).

In the absence of CD4 + T cells, high numbers of haptenspecific $\mathrm{CD} 8+\mathrm{T}$ cells producing IFN- $\gamma$ are detected in the skin-draining lymph nodes on day 5 post-sensitization, and these numbers decrease slightly with the increased magnitude and duration of CHS responses. In the presence of $\mathrm{CD} 4+\mathrm{T}$ cells, the number of hapten-specific CD8 + T cells producing IFN- $\gamma$ detected on day 5 post-sensitization is lower and quickly fall to background levels by day 7 . The limited development of effector CD8 + T cells is associated with decreased numbers of hapten-presenting DCs in the lymphoid priming site (Gorbachev and Fairchild 2004). Hapten presentation by MHC class II molecules could prime CD4 + Tregs. These results indicate that DCs can present haptenated peptides by both MHC class I and class II molecules and activate Ag-specific CD8 + effector and CD4 + Treg subsets, concurrently and independently (Krasteva et al. 1998). Eventually, the magnitude of the inflammatory reaction in allergic individuals is also tightly regulated not only by the exhaustion/apoptosis of effector $\mathrm{T}$ cells at the site of chemical challenge, but also by the intervention of Tregs. Contact allergies are the consequences of the exaggerated expansion of specific CD8 + effector T lymphocytes due to an impaired development of efficient Tregs (Cavani 2008).

Despite similar clinical reactions are present in all allergen exposure circumstances, distinct immune polarizations are characterized by different allergens. In human, although the developed ACD transcriptome due to the exposure to the most common allergens shares 149 differentially expressed genes across all allergens, a much larger gene set can be uniquely altered by individual allergens. Thereby, ACD cannot be considered as a single entity (Dhingra et al. 2014; $\mathrm{Zug}$ et al. 2009). The emerging cellular responses in ACD are mediated by various innate effector cells. Chemicalspecific $\mathrm{T}$ cells such as CD8 + and CD4 + effector cells, $\mathrm{Tc} 1 / \mathrm{Th} 1$, as well as Tc17/Th17 cells are activated (Martin 2012). Notably, the expression of CXCR3 ligands, such as CXCL9 (MIG) and CXCL10 (IP-10), are upregulated in chemical-induced allergic skin responses (Meller et al. 2007). Chemokines regulate acquired $T$ cell responses by promoting their migration into the draining lymph nodes and presentation of the contact allergens by the skin-derived antigen presenting cells. Furthermore, following this activation process, these activated CD $4+$ and $\mathrm{CD} 8+\mathrm{T}$ cells' recruitment to the skin is controlled by the chemokines (Alase and Wittmann 2012).
Both CD4 + and CD8 + T cells mediate development and progression of CHS. Hapten-specific CD4 + T cells mainly produce IFN- $\gamma$ and TNF- $\alpha$, which leads to the activation of resident immune cells at the inflamed site. Hapten-induced CHS in the skin is a delayed type cellular immune response that can be mediated by $\mathrm{CD} 8+\mathrm{T}$ cells that produce IFN- $\gamma$ or IL-17. Eventually, IFN- $\gamma$ and IL-17 mediate the elicitation of CHS by different mechanisms and both cytokines are required for optimal responses (He et al. 2009). IL-1R signaling is essential for multiple steps during the sensitization period and challenge to elicit CHS (Kish et al. 2012).

Elevated levels of IFN- $\gamma$, IL-17 $\alpha$, and IL-23, as well as increased accumulation of antigen-specific IFN- $\gamma$-producing CD8 + TRM cells occur in chronic contact hypersensitive skin. Furthermore, repeated allergen challenge may induce exacerbated allergic skin inflammation induced. However, mast cells protect the skin from this severe inflammatory condition by, at least in part, via effects on CD8 + TRM cells (Gimenez-Rivera et al. 2016). The release of histamine encourages the infiltration of inflammatory cells, including mast cells and eosinophils. Thus, this process results in the elevation of Th2 cytokine levels in chronic allergic contact dermatitis. As consequence of increased histamine, eczematous lesions develop, IgE serum levels increase, and scratching behavior in chronic allergic contact dermatitis is provoked. The administration of $\mathrm{H} 1$ or $\mathrm{H} 4$ receptor antagonists is effective to ameliorate these symptoms (Ohtsu and Seike 2017).

On the other hand, mast cells can be stimulated by cell to cell contact with $\mathrm{T}$ cells. This event results in protein kinase $\mathrm{D}$ activation, and simultaneous phosphorylation of p38, and further degranulation and release of cytokines (Salamon et al. 2016). The released IL-4 alters the phenotype of terminally differentiated human cutaneous mast cells. Prolonged contact with IL-4 not only increases mast cell expansion, but also phenotypically and functionally reshapes the cells. Furthermore, IL-4 expression augments FceRI expression on the mast cell surface, FceRI $\alpha$-specific mRNA, and FceRI-mediated histamine release. Increase in histamine production by IL-4 may contribute to its proallergic effect; thereby, this biogenic amine has a significant role for the arising of the allergic symptoms. Collectively, IL-4 alters human skin mast cells after long-term exposure. This prolonged duration mimics the chronic disorders by the increased mast cell mass and intensive processes associated with allergic inflammation (Babina et al. 2016). The elicitation of contact sensitivity is initiated by rapidly formed hapten-specific IgM antibodies that activate mast cells. Further, complement system also participates in this phase of contact hypersensitivity (Tsuji et al. 2002). Following IgE challenge by histamine-dependent mechanisms, activated mast cells induce DC migration to lymph nodes (Jawdat et al. 2004). 
Another regulatory pathway involves Tregs, producing antigen-specific exosome-like nanovesicles that deliver inhibitory miRNA. The extracellular vesicles, exosomes, are newly recognized intercellular conveyors of functional molecular mechanisms. Remarkably, they transfer RNAs and proteins between different cells that enables them to have inevitable roles in the complex pathogenesis of allergic and related hypersensitivity responses, and also, in various disease mechanisms (Nazimek et al. 2016). The microRNAs (miRNAs) seem to influence regulatory mechanisms of inflammation during the regulation of ACD (Mannucci et al. 2017). It has been shown that several different cells release phospholipid membrane vesicles that play key roles in cell-cell communication, as well as antigen presentation. Thus, these extracellular vesicles carry in addition to various proteins, mRNAs, and miRNAs (Ohno et al. 2016). Besides their role in the transmission of genetic regulation, transfer of allergens via the exosomes induces allergic inflammation. While the regulatory and tolerogenic exosomes potentially inhibit allergy and hypersensitivity responses, nonspecifically, they can also act in an antigen-specific manner due to the coating of the exosome surface with antibodies (Nazimek et al. 2016). Transferred exosomal mRNA can be translated after entering into another cell; thus these newly delivered mRNA and miRNAs can be functional in the recipient cell. In this case, this RNA is called "exosomal shuttle RNA" (Valadi et al. 2007). Significant up-regulation of miRNA-21 (miR-21), miR-142-3p, miR-142-5p, and miR-223 has been involved in the pathogenesis of allergic contact dermatitis (Vennegaard et al. 2012).

In summary, similar clinical outcomes are presented during the allergic cutaneous contact sensitivity reactions, in contrast to the distinct immune polarizations to various allergens. The cellular responses involve innate effector cells that are further challenged and regulated by adaptive responses. Moreover, T cell-derived immunosuppressive exosome-like nanovesicles reveal two important properties. First, these nanovesicles can be antigen-specific, which enables them to suppress antigen-specific contact sensitivity-effector T cells and bind to specific antigens. Second, these nanovesicles could easily be transfected with selected miRNA and, therefore, deliver a chosen regulatory RNA cargo to genetically affect the functions of targeted cells (Bryniarski et al. 2013).

\section{Immune tolerance to allergic contact dermatitis}

Classically, during the T-cell mediated suppression, both regulatory and effector cells are often specific for the same antigen. These Tregs, once activated by an antigen, the effector phase of suppression is triggered and they secrete antigen non-specific suppressive cytokines. These cytokines act to down-regulate immune responses of other specific cell populations to their respective antigen. This phenomenon is known as 'bystander suppression' or determinant spreading (Chen et al. 2014; Hoyne and Lamb 1997). ACD may develop upon defective Treg functions. CD8 + positive immunosuppressive $\mathrm{T}$ cytotoxic 2 ( $\mathrm{Tc} 2$ ) cells are suppressor cells in low-dose tolerance to haptens. Low zone tolerance (LZT) to contact allergens is induced by epicutaneous exposure to haptens in subsensitizing doses resulting in an inhibition of contact hypersensitivity (CHS), which, in contrast, occurs after sensitization with immunogenic doses of allergens (Seidel-Guyenot et al. 2004). Exposure of sub-sensitizing doses of contact sensitizers on normal skin generates $\mathrm{CD} 8+\mathrm{Th} 2$-like cells that give rise to hapten-specific tolerance (Steinbrink et al. 1996). In this context, skin physiologically uptakes very small amounts of allergenic antigens and this process results in low zone tolerization. IL-10 downregulates the expression of MHC class II and co-stimulatory molecules and inhibits the production of proinflammatory cytokines, including IL-12 by DCs and other professional antigen-presenting cells (Mocellin et al. 2003). The LZTpromoting CD4 + T cell population is the CD4 + Treg subset that can induce the generation of regulatory $\mathrm{CD} 8+\mathrm{T}$ cells. Regulatory CD8 + effector T cells of LZT produce and secrete large amounts of the Tc2 cell cytokines IL-4 and IL-10. Skin exposure to low-dose contact allergen results in the release of IL-10 by CD4 + T cells in draining lymph nodes, which promote the IL-10 - dependent development of CD8 + pre-effector cells of LZT. Development of low-dose tolerance is mediated by IL-4/IL-10-secreting CD8 + Tregs that are generated in presence of CD4 + T cells (Maurer et al. 2003). IL-10 production is critical for the suppressor function of Treg cells in mice with LZT. For the achievement of LZT, the tolerogenic CD8 + CD11c + DCs located in the skin-draining lymph nodes are essential. A critical interaction is found between CD4 + CD25 + FOXP3 + Treg cells and tolerogenic CD8 + CD11c + DCs during the induction of LZT (Luckey et al. 2012). Soluble T suppressor factor is considered as regulatory miRNA-150 transported by $\mathrm{T}$ reg-derived exosomes. These are antigen specific due to a surface coating of $\operatorname{IgM}$ antibody light chains produced by B1a lymphocytes, and these exosomes are able to suppress contact sensitization reaction (Ptak et al. 2015). Treg cells producing high levels of IL-10 suppress ACD by blocking the functions of DCs. Contrarily, CD4 + CD25 + Tregs prevent immunopathological reactions and maintain peripheral tolerance to haptens by coordinating a cell-to-cell contact mechanism (Girolomoni et al. 2004). Tolerance can be achieved by the exosome-like nanovesicles, which contain CD8 + suppressor T cells. However, these are not regulatory $\mathrm{T}$ cells. T-cell regulation can be carried out through a systemic transit of exosome-like nanovesicles. These conveyors' surface can be coated by the antigen-specific antibody light chains and can deliver an inhibitory miRNA to the target effector $\mathrm{T}$ cells. Thus, the suppressive nanovesicles 
produced during tolerogenesis could be coated with antibody light chains (Bryniarski et al. 2013).

\section{Role of extracellular matrix in ACD}

The extracellular matrix (ECM) is a complex network of macromolecules that surrounds cells in tissues and simultaneously provides cell support, tissue organization, and helps regulate essential cellular functions (Neill et al. 2015; Pozzi et al. 2017; Nikitovic et al. 2012, 2014).

The two basic structures of the ECM are basement membranes, which are organized as thin layers of highly crosslinked biomolecules, and the loose array of fibrillar macromolecules which create the interstitial matrix. Importantly, the basement membranes form supporting platforms for "anchored cells", and in skin define the boundary between the epidermal and dermal compartments. Thus, the basement membranes have the role of a stabilizing, but simultaneously dynamic interface and a diffusion barrier (Krieg and Aumailley 2011; McMillan et al. 2003). The properties of dermal ECM, mostly constituted from type I and III collagen fibrils, elastic fibers, hyaluronan and a ground substance of proteoglycans define dermal tensile strength and elasticity (Krieg and Aumailley 2011). However, through their supporting function and signaling properties basement membranes have a prominent role in skin homeostasis (Yurchenco 2011). Indeed, both the basal membranes and interstitial matrix though exquisite in-out and out-in signaling modulates important aspects of cell behavior such as adhesion, migration, growth, metabolism, survival or differentiation (Sher et al. 2006; Zoeller et al. 2009) Inflammation induced changes in skin basement membrane diminish their barrier properties and impinge skin cohesiveness (Shin et al. 2015). Furthermore, the degradation of ECM in most tissues is likely to contribute to both initiation and maintenance of inflammation (Nikitovic et al. 2015; Kavasi et al. 2017) as well as being a significant component of the activating stroma reaction in cancer (Mueller and Fusenig 2004; Nikitovic et al. 2013).

HA, a high molecular weight glycosaminoglycan (from $10^{5}$ to $10^{7}$ ), produced in the skin mostly by dermal fibroblasts, is an important component of skin ECM (Tzellos et al. 2011). In fact, almost 50\% of the total HA in the body is deposited to the skin (Meyer and Stern 1994). Noteworthy, epidermal keratinocytes also produce HA, with the spinous and the granular layers depositing HA to ECM, whereas at the basal layer it is located intracellularly (Stern and Maibach 2008). HA, a glycosaminoglycan, is in mammals, produced by the three hyaluronan synthases (HAS1, HAS2, and HAS3) as high-molecular-weight hyaluronan (HMWHA) (Weigel et al. 1997). HMWHA, normally secreted by healthy tissue cells, interacts with proteoglycans and other matrix macromolecules contributing thus, to the formation of the
ECM network (Weigel et al. 1997). The properties of HA are directly dependent on its molecular weight. Indeed, HMWHA deposited during the homeostasis process promotes tissue stability (Noble 2002). Specifically, HMWHA polymers suppress angiogenesis, immune response and inflammation (Stern et al. 2006; Kim et al. 2008), as well as cell differentiation through interactions with HA-specific receptors such as CD44 and RHAMM (Stern et al. 2006).

During inflammation or injury, ECM is remodeled and active mediators-matrikines released. Such matrikines are low molecular weight hyaluronic acid (LMWHA) fragments that act as DAMPs (Stern et al. 2006; Schaefer 2014). LMWHA results either enzymatically through the action of HA-digesting enzymes, mostly hyaluronidase 1 and 2 (HYAL1,2), or chemically via the action of reactive oxygen species (ROS) (Agren et al. 1997; Monzon et al. 2010).

Under conditions of skin inflammation, secreted inflammatory enhancers modify the transcription of HAS and HYAL genes resulting in the release of LMWHA as recently discussed (Kavasi et al. 2017). The released LMWHA fragments contribute to the mechanisms of "sterile" inflammation including the onset of contact dermatitis. Thus, exposing human keratinocytes to contact allergens, paraphenylenediamine (PPD) and 2,4-dinitrochlorobenzene, resulted in decreased HA deposition to ECM and increased expression of HYAL1 and HYAL2 (Nikitovic et al. 2015). Importantly, this study identified a correlation between HA degradation and IL-18 production. Noteworthy, allergendependent production of IL-18 was reduced after incubation with HYALs, i.e. IL-18 was reduced under conditions of complete degradation of HA to tetrasaccharides (Nikitovic et al. 2015). Also, in the same study it was shown that exposing human keratinocytes to LMWHA is sufficient for the induction of sensitization and that direct interaction of LMWHA with CD44 receptors is required (Nikitovic et al. 2015).

Several reports suggest that the CD44-HA binding complex affects signaling pathways associated with inflammation such as those of the transcriptional nuclear factor kappa B (NF-kB) (Campo et al. 2010), protein kinase C (PKC), Rho- kinase or protein kinase-N $\gamma$ (Bourguignon 2014; Bajorath 2000). Indeed, HA stimulation of CD44 activates PKC, which in turn activates NF-kB, responsible for the expression of inflammatory mediators, such as TNF- $\alpha$, interleukin-6 (IL-6) or IL-1 $\beta$ (Campo et al. 2010). Furthermore, it has been demonstrated that the CD44 receptor, through the formation of a complex with the TLR4 receptor (TLR4CD44), mediates the release of inflammatory cytokines (Taylor et al. 2007).

The involvement of HA in the induction of sterile skin inflammation by contact allergens was likewise shown in a mouse model. Indeed, when mouse skin was exposed to the strong skin sensitizer 2,4,6-trinitrochlorobenzene 
(TNCB), following pre-treatment with a HA-binding peptide Pep1 (Zmolik and Mummert 2005), a decreased level of inflammation was achieved (Martin et al. 2008). In the same model, Esser et al. (2012) demonstrated that the pre-treatment of the skin with antioxidants or aristolochic acid, a hyaluronidase inhibitor, decreased contact allergen-induced sterile skin inflammation. These authors, therefore, suggest that the LMWHA fragments which are generated through chemical or enzymatic HA-cleavage can act as DAMPs in the process of keratinocyte activation (Esser et al. 2012; Nikitovic et al. 2015; Corsini et al. 2013). In a separate study, long term treatment of epidermal keratinocytes with methyl paraben resulted among other in decreased expression of HAS 1 and 3 and collagen type IV while at the same time it enhanced the expression of HSP27 and involucrin (Ishiwatari et al. 2007), well established to be differentiation markers in normal human epithelial keratinocytes (NHEK) (Kindas-Mugge and Trautinger 1994; Robinson et al. 1996). On the other hand, HMWHA was shown to exert an anti-allergic effect through targeting CD44 and inhibiting FcepsilonRI signaling in a mice model of DNFB-induced atopic dermatitis (Kim et al. 2008).

HA involvement in the progression of other inflammatory skin disease has likewise been implicated. Indeed, in the case of acute eczema there is an up-regulation of HAS3 mRNA expression and increased secretion of HA to the ECM, followed by decrease in cadherine expression and epidermal keratinocyte cohesiveness leading to water inflow (Ohtani et al. 2009). In biopsies from atopic dermatitis patients HAS3 expression was likewise shown to be enhanced, while HAS1 was downregulated (Malaisse et al. 2014). Furthermore, Malaisse et al. (2014) indicate that HAS1 is the main enzyme responsible for HA production by normal keratinocytes and suggest that the equilibrium in HA levels obtained by respective expressions of separate HAS isoforms may be crucial in the progression of different keratinocyte pathologies (Malaisse et al. 2016). Other studies suggest that HAS3 action accounts for HA synthesis in keratinocytes, while HAS1 is mainly responsible for fibroblast HA synthesis (Sayo et al. 2002; Yamada et al. 2004).

Biological functions of various skin cell types including dendritic cells were found to be regulated by changes in HA metabolism. Thus, in mice genetically modified to overexpress HYAL1 which results in increased HA degradation, DC cells show increased migration from the skin which is suggested to result from enhanced production of LMWHA fragments (Muto et al. 2014). In the same model, a notable observation is that HA degradation resulted in faster antigen presentation and activation of immune response. Specifically, HYAL1 overexpression before the application of an allergic antigen results in the suppression of immune response, while simultaneous HYAL1 overexpression and antigen application lead to a faster response (Muto et al. 2014).

Other ECM components have also been implicated in the process of skin hypersensitization. Thus, osteopontin is a secreted ECM phosphoprotein where it exhibits dual roles. It simultaneously acts as a chemoattractive cytokine and as an ECM component involved in the interactions of the cell with its environment (O'Regan et al. 1999; Liaw et al. 1995). Weiss et al. show that osteopontin initiates the chemotactic migration of dendritic cells, inducing their subsequent emigration from the epidermis, and finally attracts the migration of these cells to draining lymph nodes through its specific interactions with CD44 and alpha integrin expressed on these cells surfaces (Weiss et al. 2001). Moreover, dendritic cells may utilize osteopontin to convert naive $\mathrm{T}$ cells into Tregs (Kraus et al. 2018). In addition, patients affected by acute disseminated ACD exhibit increased serum concentration of osteopontin, directly correlated with ACD severity (Reduta et al. 2015).

Proteoglycans have also been implicated in the mechanisms of skin hypersensitivity. Thus, recently it was shown that the expression of syndecan-4, a heparan sulfate proteoglycan, was upregulated in both serum and skin biopsies of AD patients. These authors therefore suggest that syndecan-4 may participate in the pathogenesis of AD (Nakao et al. 2016). Interestingly, another family member, syndecan-1, was found to negatively regulate the migration capability of dendritic cells (Averbeck et al. 2017). The role of ECM components is depicted in Fig. 1.

In conclusion, available data suggests, a significant participation of the skin ECM in the processes of sterile inflammation and the possibility of utilizing ECM components as targets/biomarkers for conditions of skin hypersensitivity.

\section{Insights the potency of contact allergens from a regulatory perspective}

Toxicological evaluations are carried out through hazard identification and subsequently with the assessment of whether that hazard is likely to translate into a health risk. An accurate evaluation of the relative potency of skin sensitizing chemicals is an important challenge that can lead to improvements in hazard classification and can facilitate skin sensitization risk assessment (Kimber et al. 2003). Risk assessment strategies serve to ensure that human exposure to skin sensitizers is managed in accordance with their potency. As broad meaning, the word potency is used as a descriptor for strength, power or vigor, this also applies to skin sensitization. Potency refers to the intrinsic property of a sensitizing chemical and is based in the concentration of chemical needed to induce a positive response. Allergens are known to vary significantly as much as 10,000 -fold in relative sensitization potency with which they can induce skin 
Fig. 1 The role of ECM in mechanisms of skin sterile inflammation. a Contact of sensitizers with keratinocytes modulates HA production; $\mathbf{b}$ synthesized high molecular weight HA is degraded to LMWHA fragments through action of hyaluronidases (Hyal) or radical oxygen species (ROS); c LMWHA binds to the CD44 cell membrane receptor; $\mathbf{d}$ receptor-ligand binding activates downstream intracellular pathways which result in transcriptional upregulation of inflammation mediators; $\mathbf{e}$ increased deposition of specific ECM components enhances dendritic cell chemotactic migration and activation or protraction of the immune response

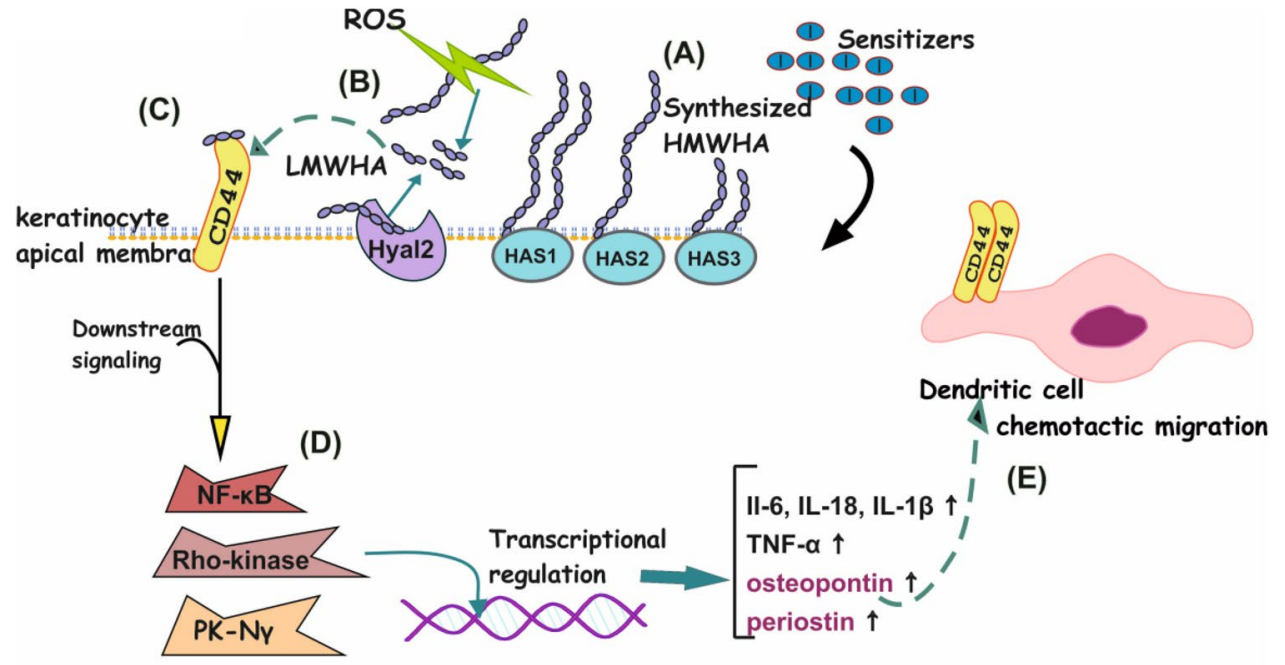

keratinocyte basal membrane

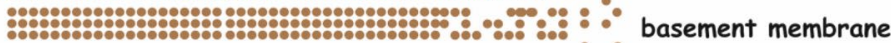
degradation sensitization (Basketter and Kimber 2009). In this context, it is also important to distinguish potency as it relates to the activity of sensitizing chemicals from the relative prevalence of allergic contact dermatitis in humans (i.e. nickel), as this requires human data, which are not available for new chemicals.

Potency is defined as a function of the concentration of substance that is required for either induction or elicitation of skin sensitization. For the induction phase, potency refers to the dose of a chemical needed to cause the acquisition of sensitization. The more potent the substance is the smaller quantity will be needed for induction. Likewise, for the elicitation phase, potency is described in term of the dose of a substance needed to elicit a response in a previously sensitized individual. Again, the more potent the substance is the less that will be required to elicit a reaction (Friedmann et al. 1983).

The identification of the mechanisms influencing the vigor of $\mathrm{T}$ cell responses that can explain the strength of contact hypersensitivity reactions to weak, moderate, strong, and extreme sensitizers is a challenge still to be solved. Several hypotheses have been made as also discussed in the previous paragraphs, one possibility is that the extent/degree of chemicals allergen-induced KCs-DCs activation/maturation and lifespan may drive T cell polarization (e.g. Th1, Th2, Treg) and the magnitude of activation, which may then result in different in vivo potency.

What drive variation in the human immune response to contact allergens of different potency is still little known. Nevertheless, relative skin sensitizing potency of contact allergens represents an important component of risk assessment. From a toxicological perspective, to achieve a complete replacement of animals in skin sensitization assessment, dose-response information and evaluation of relative skin sensitizing potency to support effective risk assessment are necessary.

Contact allergens are haptens, that are too small to trigger an immune response themselves. Gerberick et al. proposed that the vigor of the immune response elicited by contact sensitizers of different potency might correlate with chemical reactivity with proteins or peptides (Gerberick et al. 2007). This chemical reactivity determines the number of different proteins that become haptenated, that translated into the number of T cell epitopes (Esser et al. 2014). Strong sensitizers are believed to generate a high number of cross-reactive $\mathrm{T}$ cell epitopes, and as consequence, the size and $\mathrm{T}$ cell receptor (TCR) repertoire diversity of the $\mathrm{T}$ cell pool is expected to be higher compared to the pool activated by weak contact allergens (Esser et al. 2014). It has been reported that more $\mathrm{T}$ cell clones respond to a strong sensitizer compared to a weak sensitizer but is it not clear whether the extent of exposure will also impact on Treg responses (Nakao et al. 2016). Studies in mouse models of skin sensitization have shown that strong skin sensitizers result into a broader range of modified peptides, inducing a $\mathrm{T}$ cell response with a higher frequency of CD8 effector $\mathrm{T}$ cells (Taylor et al. 2007). A recent study from Oakes et al. reported the possibility of global analysis of the T cell repertoire, through a robust single-strand DNA ligation protocol, which tags each molecule of TCR. They characterized the in vitro $\mathrm{T}$ cells response from individuals sensitized to para-phenylendiamine (PPD), a strong skin sensitizer. PPDhuman serum albumin (PPD-HAS) conjugate showed to induce proliferation of a subset of peripheral blood $\mathrm{T}$ cells 
from sensitized individuals, which manifest as different degrees of in vitro expansion (Oakes et al. 2017).

In addition, the magnitude of the skin innate inflammatory response induced by contact sensitizers may translate into the efficiency of overcoming constitutive immune regulatory mechanisms and into the number of DCs that become activated in the skin and then migrate to draining lymph nodes with priming of contact sensitizer-specific naive $\mathrm{T}$ cells (Esser et al. 2014). Allergens of different potency may differently activate DCs. Galbiati et al. demonstrate that a combination and regulation of HuR and TTP, proteins involved in mRNA stabilization, following exposure to contact allergens of different potency (namely DNCB, diethylmaleate and isoeugenol) resulted in a different modulation of IL-8 mRNA half-life and release, which correlated well with potency, with the strong allergen DNCB failing to upregulate TTP, while inducing HuR, resulted in longer IL-8 mRNA half-life and protein release (Galbiati et al. 2012). These results also support the idea that chemical allergens of different potency may differently activate DC.

\section{The case of nanoparticles and hypersensitivity reactions}

Nanoparticles (NPs) are primarily defined by their submicron size, which exhibit a multitude of discrete characteristics as regarding their shape, surface structure and functionality, material and encapsulation efficiency (Goldberg et al. 2007; Neagu et al. 2017; Piperigkou et al. 2016). Numerous NP types have already been generated, including ceramic-, metal-, and carbon-based NPs; polymeric NPs; exosomes; liposomes; and scaffolds (Bhatia 2016). In order to increase their specificity, nanomaterials are usually associated with various coatings or ligands, or with active compounds such as drugs or tracers that can be adsorbed or incorporated (Coricovac et al. 2017; Kuskov et al. 2017). Importantly, generated nano-systems are often "multitasking" and may support in parallel both diagnostic and treatment purposes (Chen et al. 2014). In spite of their huge application potential NPs may also exert deleterious side effects, including toxicity (Bhatia 2016; Galbiati et al. 2018; Pinzaru et al. 2018; Kuskov et al. 2016).

The question of NP interaction with the skin barrier is important as regarding both its clinical and potentially hazardous environmental effects. Thus, the ability of NPs to penetrate the healthy skin barrier has been debated. Generally, three routes of transdermal drug penetration have been described the paracellular, transcellular and follicular (appendages) pathways (Bhoyar et al. 2012). As regarding NPs transport, recently, it was shown that fluorescently tagged 20 and $200 \mathrm{~nm}$ polystyrene NPs largely gathered in the stratum corneum and in the upper part of vellus hair follicles; whereas deeper penetration into the stratum corneum and localization to infundibulum of vellus hair follicles were found to be infrequent events (Döge et al. 2018).

On the other hand, NPs were shown in murine and pig atopic dermatitis models to penetrate into the skin barrier exclusively in the region of inflamed skin. Importantly the penetration of these poly(l-lactide-co-glycolide) NPs was size and species dependent (Try et al. 2016). Uptake of NP by human epidermal cells in vitro was affected by their surface functionalization and size as well as by their ability to form aggregates. The same authors in partially breached human skin explant model demonstrate that small sized NPs, independently of functionalization associate with epidermal cells and especially dendritic cells (Rancan et al. 2012). In an in vitro skin model nickel NPs were found to penetrate the epidermis and enter the dermis. This penetration however was found to be several-fold higher in abraded skin (Crosera et al. 2016). Collectively, these data indicate that an evaluation of NP-skin cells interactions under conditions where a breaching of skin barrier is evident e.g. atopic dermatitis and chronic eczema is obligatory in order to assess possible risks of intended and unintended particle exposure. Thus, zinc oxide ( $\mathrm{ZnO})$ NPs, used as a component of sun screens, were shown to penetrate both injured and allergy injured mouse skin. Interestingly, in this study ZnO-NPs were shown to attenuate the local skin inflammation induced in the mouse model of $\mathrm{AD}$; but they were able to activate systemic production of IgE antibodies. Therefore, it is suggested that $\mathrm{ZnO}$-NPS exhibit adjuvant properties in allergy promotion (Ilves et al. 2014). Likewise, $\mathrm{TiO}_{2}-\mathrm{NPs}$ were shown to upregulate the ability of dinitrochlorobenzene to induce dermal sensitization after topical exposure (Smulders et al. 2015). Moreover, when silica NPs and mite allergen combination was topically applied in a mice model, a low $\mathrm{IgG} / \mathrm{IgE}$ ratio was determined. This result is important, as low $\mathrm{IgG} / \mathrm{IgE}$ ratio is considered to be a major risk factor of human atopic allergies (Hirai et al. 2015). Another, important issue to consider is the ability of NPs to induce ACD. Thus, Potter et al., complying with the directive for reducing the use of research animals have adapted the human cell line activation test (hCLAT) and myeloid U937 skin sensitization test (MUSST or U-SENS), for assessing nanomaterials (Potter et al. 2018).

Importantly, NPs have also been evaluated as drug carriers for atopic disease and evidence of their efficient performance due "to their pharmaceutical versatility, longer retention time at the target site, avoiding off-target effects and preventing premature degradation of the incorporated drugs" is discussed by Shao et al. (2016). Therefore, focused application of tested NPs may significantly contribute to therapy for atopic skin disease.

In summary, the potential side effects of nanomaterials need to be taken into account seriously in their role as 
initiators of $\mathrm{ACD}$ as especially for their suggested adjuvant effects.

\section{In vitro models for assessing contact allergen-induced cell activation}

\section{International network to standardize in vitro tests}

Regulatory authorities worldwide require testing for skin sensitization and appropriate hazard labeling to minimize exposures. Well established animal methods for contact and respiratory hypersensitivity exist. Animal models, including the murine LLNA, are strictly regulated by recent legislations, thus new reliable in vitro alternatives are needed to replace animal assays to fulfill regulatory constraints. The European 7th Amendment to the Cosmetics Directive marked the common international view that animal tests should be replaced with alternative test, but also rise the concern that the complexity of a pathological reaction could only be matched by multiple in vitro assays (Coricovac et al. 2017).
The publication of the AOP for skin sensitization prompted the development of a variety of non-animal tests and paved the way for integrated approaches to testing and assessment (IATA) in regulatory decision-making within OECD Member Countries in the area of skin sensitization. In Fig. 2, the AOP is schematically reported together with the state of the art of in vitro alternatives both validated and not validated covering the different key events. Recently, the OECD released new test guidelines for skin sensitization, including the direct peptide reactivity assay (DPRA, OECD TG 442C), the Keratinosens ${ }^{\mathrm{TM}}$ and LuSens ${ }^{\mathrm{M}}$ assays (OECD TG442D), the human Cell Line Activation Test (h-CLAT), the U937 cell line activation test (U-SENS ${ }^{\mathrm{TM}}$ ), and the Interleukin-8 Reporter Gene assay (IL-8 Luc assay) (OECD TG $442 \mathrm{E}$ ), which cover the first three key events described in the AOP.

Several international agencies, including the American Interagency Coordinating Committee for the Validation of Alternative Methods (ICCVAM), EURL-ECVAM (European Union Reference Laboratory for alternatives to animal testing) and JaCVAM (Japanese Center for the Validation of Alternative Method) are extremely active in validating

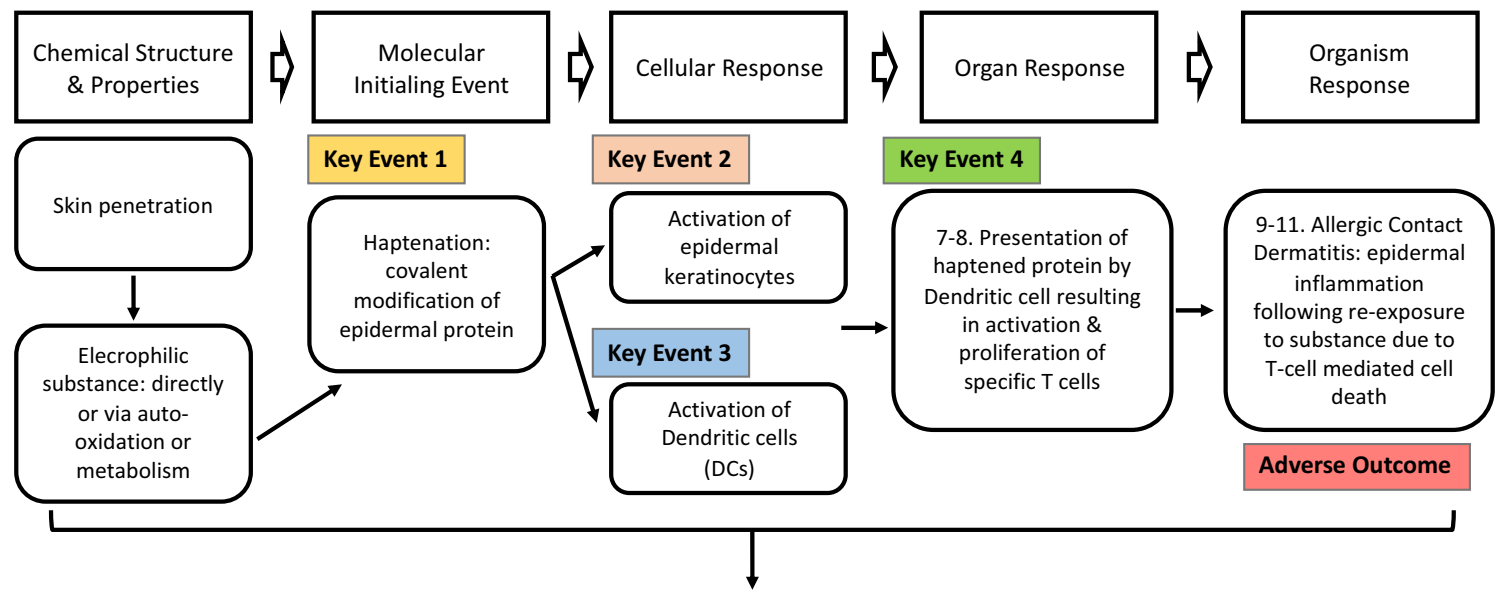

Adverse Outcome Pathway and associated assays

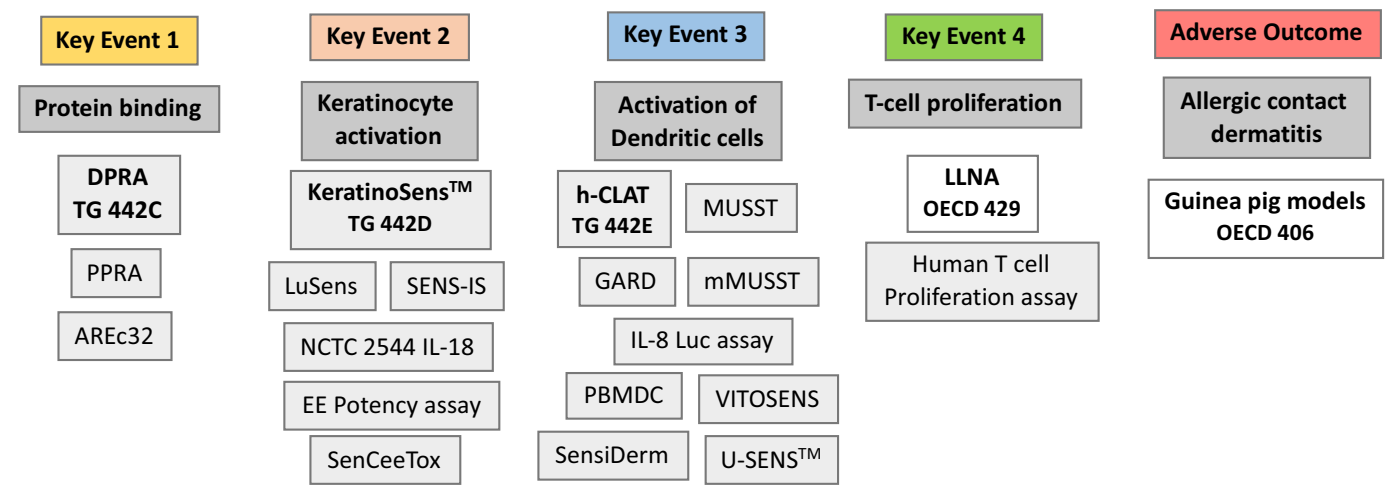

Fig. 2 Schematic view of the AOP for skin sensitization and associated assays. In bold the validated methods are reported, and not in bold other methods addressing the different key events 
non-animal alternatives to test chemicals for skin sensitization potential (Strickland et al. 2016, 2018). In addition, an important role of these agencies is also to support the regulatory acceptance and facilitate the use of non-animal approaches. An important initiative worth mentioning is the NTP (National Toxicology Program) currently testing of approximately 200 chemicals in three in chemico/in vitro assays: the direct peptide reactivity assay, the LuSens assay, and the hCLAT. All testing is expected to be completed in early 2019.

Some of these in vitro methods are described below in details.

\section{In vitro models}

The adoption of the 7th Amendment to the Cosmetics Directive, reducing animal testing and enlarging the in vitro models for predicting the sensitizing capacity of compounds has boosted the research in this domain. Human cell explant, human cell lines from a single cell type to organotypic multicellular reconstructed 3D skin models have been tested for their predictivity (Aeby et al. 2007; Jäckh et al. 2012). Most of the tests measure specific surface markers, cytokine production, as well as genomic biomarkers. In silico models are also explored to predict the biological behavior of a compound and aid the in vitro experimental models (Boverhof et al. 2008).

The evaluation of the skin sensitization potential of chemicals is an important safety issue and a concern of regulatory bodies, as mentioned above. All new ingredients to be incorporated into a product can have the potential to be skin allergens.

Taking into account the array of cells, mediators and complex inter and intracellular events developed by this pathology triggered by allergens (Toebak et al. 2009; Galli and Tsai 2012; Ehling et al. 2016), the history of developing in vitro assays that can evaluate it had a myriad of branches and developments.

One of the first published papers regarding in vitro tests for contact sensitizers' identifications stated that the main hurdle is to mimic the appropriate application of allergens in in vitro approaches. The difficulties were pointed out, as most of the allergens need antigen presenting route and this process is sustained by the complex skin tissue. Moreover, allergens can have poor solubility in culture media. Thus, in the 1990, in vitro lymphocyte activation was the most promising testing method. Lymphocyte transformation and macrophage migration inhibition were developed (von Blomberg-van der Flier and Scheper 1990). Then, several experimental avenues were opened. Short-term human skin cultures after in vivo contact with the allergens were tested, cultures in which Langerhans cells (LC) preserved their characteristics (Rambukkana et al. 1996). These results suggested that cultivation of ex vivo human skin explants provided the first clue that in vitro allergenicity of compounds can replace in vivo animal models (Pistoor et al. 2016) and that skin equivalent can be used for in vitro testing of allergens (Gerberick and Sikorski 1998).

At the end of the 1990s a boost of alternative in vitro models appeared. In parallel with the experimental tests, in silico models were initiated, models that were studying the relation between structure and biological action (SARs). Molecular and/or physicochemical properties can predict and quantify the allergenic potential of a molecule before any biological test. Thus, the allergy databases was initiated, the design of computerized systems and the development of quantitative SARs (QSARSs) (Lepoittevin 1999) were started at the end of the 90 decade.

Not surprisingly, the first cell that got the attention for in vitro models was LC, as the main antigen-presenting cell in the skin. Cultivation of immature DCs from peripheral mononuclear blood cells was used in order to overcome some technical draw-backs that rose from directly isolating skin's LCs. Several sensitizers were tested $\left(\mathrm{NiSO}_{4}\right.$, dinitrochlorobenzene, 2,4,6-trinitrobenzene sulfonic acid, alpha-hexylcinnamaldehyde, and eugenol) and all tested skin sensitizers induced the up-regulation of several molecules, co-stimulatory molecule CD86, intercellular adhesion molecule CD54 and HLA-DR antigen (Tuschl and Kovac 2001). These early reports have emphasized that suitable approaches can be developed using DC culture systems (Nakao et al. 2017). Developing the DC in vitro models, migration and maturation of cells were studied in order to evaluate skin sensitizing potential. A set of methacrylate congeners were tested in in vitro models, using blood monocyte-derived DC. Out of the entire studied panel of activation markers, CD86 and CXCR4 were the most sensitive in discriminating between the contact sensitizers and irritants. Ex vivo skin explant cultures confirmed that LC were induced to migrate upon allergens' action from epidermal to basal membrane and that the migration extent correlated with the sensitizing action of the compounds. Thus, the increased expression of the chemokine receptors in the blood monocyte-derived DC were confirmed by the ex vivo model (Rustemeyer et al. 2003). More recently, photoallergenic capacity of compounds was tested using DCs derived from human peripheral blood monocyte and all photosensitizers induced an increase of CD86 expression (Karschuk et al. 2010).

Migration capacity of LC induced by allergens was also the subjected of an inter-laboratory validation approach using human organotypic skin explant culture (HOSEC) model. Screening 23 low molecular weight allergenic compounds with HOSEC, the test could discriminate between a sensitizer and a non-sensitizer as compared to standard animal models (Lehé et al. 2003). Continuing their studies 
on HOSEC model, the same group blindly tested seven chemicals, using HOSEC model and added the information that combination of increased epidermal LC migration, LC maturation and increased expression of LC activation markers should be taken into account in this model (Lehe et al. 2006).

Other cells that got the attention of in vitro models developers were $\mathrm{KC}$ and the combination of KC's proinflammatory cytokines secretion and DC complex processes were reported. The cytokine release done by $\mathrm{KC}$ and the DC's marker expression presented above can add important information to new in vitro models. In a murine cell KC line, the evaluation of intracellular IL-1 alpha and IL-18 can bring new information on the sensitizing potential of a compound. The report concludes that the combinations of DCs markers and KC pro-inflammatory secretion can lead to a more reliable in vitro model (Vandebriel et al. 2005).

Using cell lines was the further step for developing in vitro models. Hence, an inter-laboratory validation has used THP-1 cells (human monocytic leukemia cell line) and U-937 (human histiocytic lymphoma cell line) (Sakaguchi et al. 2006). This report represented the beginning of h-CLAT protocol that later entered ECVAM recommendations. Validation was performed on 9 chemicals and the expression of CD86 and CD54 on THP-1 and U-937 cell lines was assessed. The report shows that discrimination between allergens and non-allergens was done better by THP-1 and that h-CLAT test can be an in vitro skin sensitization model of prediction (Sakaguchi et al. 2006; Nukada et al. 2013).

In a human keratinocyte cell line NCTC2455, intracellular IL-18 production was assessed in presence of low molecular weight skin allergens respiratory allergens and irritants All tested contact sensitizers induced after $24 \mathrm{~h}$ of exposure a dose-related increase in IL-18, while irritants and respiratory compounds did not (Corsini et al. 2009). The same group has taken forward their research and has shown that comparable results can be obtained using primary human keratinocytes or other human keratinocyte cell lines (e.g. HaCaT, HPKII) (Galbiati and Corsini 2012). Combining the epidermal equivalent (EE) potency assay with IL-18 was reported to provide a single test for skin sensitizing compounds. 3D different models were assessed (in house VUMC model, epiCS ${ }^{\circledR}$, MatTek EpiDerm ${ }^{\mathrm{TM}}$ and SkinEthic ${ }^{\mathrm{TM}}$ RHE. 17 contact allergens and 13 non-sensitizers were tested and a clear increase in IL-18 release was registered after $24 \mathrm{~h}$ of exposure to contact allergens Gibbs et al. 2013; McKim et al. 2012). Another report tested 400 compounds from the cosmetic industry in order to distinguish between sensitization and irritations. Sensitization process was assessed also by measuring IL-18 production by KC (Guyard-Nicodème et al. 2015).
Besides IL-18 production, another pathway that is induced by sensitizers is the Keap1-Nrf2-ARE pathway. Using four $\mathrm{KC}$ in vitro models (primary human $\mathrm{KCs}$, human immortalized N/TERT monolayer cultures, Leiden Epidermal models_-LEMs and N/TERT epidermal modelNEMs) the Nrf2 protein level and the transcriptional targets of Nrf2 were measured upon exposure to DNCB and irritant SDS at nontoxic concentrations. The Keap1-Nrf2ARE pathway is activated by the sensitizer DNCB in LEMs, NEMs, and monolayer keratinocytes but is not activated by the irritant SDS. These data show that the N/TERT models can be an alternative model for skin sensitizer identification (Alloul-Ramdhani et al. 2014).

Gathering information spanning the first decade of the years 2000, reviewed by dos Santos in 2009, cell-based assays focusing on DCs CD34 +, monocyte derived DCs and appropriate cell lines (THP-1, U-937, MUTZ-3, KG-1, HL-60, and K562) were used to develop new in vitro tests. All these tests highlighted the importance of activation/maturation markers and the release of cytokines and chemokines. The authors highlight that the solution should a multiple cell assay investigating multiple markers rather than a single cell-single market approach (dos Santos et al. 2009).

Another approach to assess chemical allergens is the non-cellular approach based on the fact that electrophilic allergens interact with nucleophilic amino acids within the proteins. Compounds with known allergenic potential and non-allergenic were tested for their reactivity to react with reduced glutathione (GSH) or with single cysteine or lysine synthetic peptides. The reaction could be compared with standard animal model testing (e.g. local lymph node assay). It was shown that non-allergens and weak allergens had very low peptide reactivity, while potent allergens exhibited high peptide reactivity. This a-cellular model could give a prediction accuracy of $89 \%$ (Friedmann et al. 1983) and a validated peptide reactivity concept (Mutschler et al. 2009).

Co-culture-based methods were the following step taken forward in the in vitro tests. Loose-fit coculture-based sensitization assay (LCSA) was developed using human monocytes differentiated to DCs and allogenic KC. The expression of CD86 as sensitizing-related a marker and the uptake of the viability stain 7-AAD as a marker of irritation were quantified within the test. These data were compared to the validated animal-based sensitization test (LLNA, OECD TG 429). This comparison showed that sensitizers were better discriminated from non-sensitizers and irritants. Thus these tests matches EU's program for the safety of chemicals "Registration, Evaluation, Authorization and Restriction of chemical substances" (REACH 2006) to replace animal models (Wanner et al. 2010). In 2017, LCSA assay was improved by replacing $\mathrm{KCs}$ with $\mathrm{HaCaT}$ cell line and co-cultivating them with peripheral blood mononuclear cells in conditions that generate $\mathrm{CD} 1 \mathrm{a}+/ \mathrm{CD} 1 \mathrm{c}+\mathrm{DCs}$, a cellular population with a marked 
up-regulation of CD86 upon contact allergens. The recently improved test identified all sensitizers including weak contact allergens (propylparaben) and resorcinol (that is not detected by the "classic" LCSA). Three out of four non-sensitizers were correctly identified; thus the improved LCSA has an increased sensitivity and discriminatory power (Frombach et al. 2017).

Another recently described in vitro model is the 3D co-culture of $\mathrm{HaCaT}$, mimicking the epidermis barrier, and human leukemic monocyte lymphoma cell line (U937) as DCs. This 3D microenvironment higher values of TEER compared to static culture were obtained, higher cell viability and a physiological milieu of air-liquid interface mimicking the skin (Ramadan and Ting 2016). Another recently published 3D model-SENS-IS - is based on a reconstructed human skin model (Episkin). An inter-validation study in three laboratories tested 19 blind coded chemicals using SENS-IS and the study showed that besides being a robust test it has high predictivity and very good reproducibility. The same data were obtained also in other reports on 150 tested chemicals, SENS-IS predicting hazard and potency characteristics (Cottrez et al. 2016; Teunis et al. 2013).

\section{Data integration}

Considering the complexity of the induction of skin sensitization and the important health consequences, it was clear from the beginning that one single test would not be sufficient to identify the allergenic potential or not of a chemical (hazard identification), to fulfill regulatory requirements on the skin sensitization potential (classification and labeling) and potency of chemicals (quantitative risk assessment). Despite its complexity, the key biological events of the process have been well characterized in the AOP, and several integrated approaches to testing and assessment (IATA) and defined approaches have been proposed to enable prediction of skin sensitization hazard through high throughput screening assays and in silico models. Recently published reviews and OECD test guideline provide the state-of-the-art of data integration and best practices for implementation of defined approaches to skin sensitization testing and assessment, and this aspect would not be covered in this review. Computational approaches represent indeed promising tools to effectively integrate data sources to identify potential skin sensitizers without animal testing (Strickland et al. 2016, 2018; OECD 2014; Casati et al. 2018).

\section{Risk prevention: what can be done to make contact allergy history?}

The fact that a chemical is a contact allergen does not mean that it cannot be formulated into a consumer product at levels well tolerated by most individuals (Robinson et al. 2000).
Many common cosmetic ingredients, such as fragrances and preservatives, are known contact allergens. Skin sensitization risk assessment of new ingredients or products is, therefore, critical before their introduction into the marketplace also including aggregating dermal exposure (Gerberick and Robinson 2000; Ezendam et al. 2018). Due to a dose-response relationship for both induction and elicitation phases of contact hypersensitivity, it is possible to determine the thresholds for the level of chemicals exposure below which sensitization will fail to be induced in a naïve subject, or below which a reaction will fail to be elicited in a previously sensitized subject (Kimber et al. 1999, 2003). Even if threshold can be established, it is important to take into consideration that thresholds: (1) can be influenced by the vehicle or formulation in which the chemical is dissolved, and subsequently exposed to skin surface; (2) for the induction of sensitization to a particular chemical will be different (higher) from the amount required to elicit a reaction in a previously sensitized subject; (3) vary between individuals, in particular for the elicitation phase of allergic contact reactions (Kimber et al. 1999). This implies that opportune safety factors must be introduced when performing quantitative risk assessment. Based on these considerations, one should be able to use contact allergens into products at levels that produce acceptably low incidences of skin sensitization under foreseeable conditions of exposure (Robinson et al. 2000).

While exposure for other endpoints is usually expressed in units of $\mathrm{mg} / \mathrm{kg}$ body weight, the relevant dose metric for skin sensitization potential is the amount of chemicals allergen per unit area on the skin (Robinson et al. 2000). Human skin sensitization studies have indeed demonstrated that the key factor in the induction of skin sensitization is the dose of the substance per unit area of skin (Basketter and Kimber 2009; Rees et al. 1990; White et al. 1986). Thus, it is recommended that sensitization threshold obtained from animal and human data be expressed as the dose per unit area of skin (Boukhman and Maibach 2001). Typically, risk assessment for skin sensitization include structure activity relationship analysis, exposure assessment, preclinical testing (e.g., local lymph node assay and clinical testing, e.g., human repeat insult patch testing if available) (Gerberick and Robinson 2000).

Coming to alternative to animal testing, despite the importance of potency estimation in the development of accurate risk assessment, there has been relatively modest progress in the definition of appropriate experimental in vivo and consequently in vitro models (Basketter et al. 2000). The availability of a robust and reliable method for assessment of relative skin sensitizing potency is of considerable importance for the classification of contact allergens and for the development of accurate assessment of risk (Nakao et al. 2016; Rees et al. 1990; Loveless et al. 2010). Currently 
Fig. 3 GHS classification categories for skin sensitization

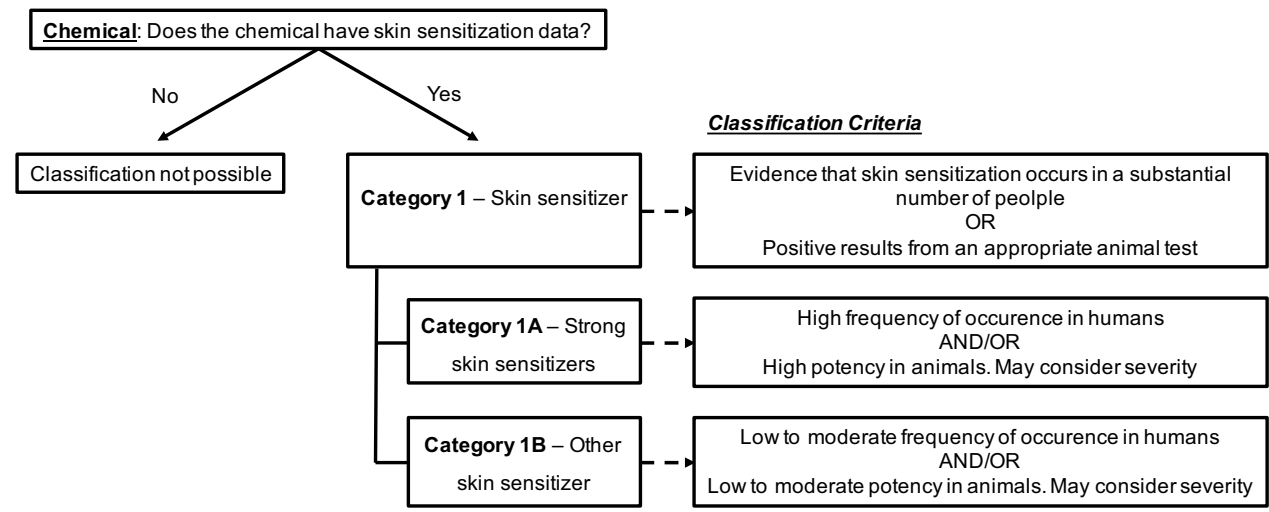

the LLNA is the preferred method for the identification of contact allergens since it provides an accurate and reliable identification of skin sensitization hazards and has proven to be useful also for the relative potency information (Kimber and Pallardy 2014). Understanding the biological mechanisms underlying the potency of an allergen and the possibility of defining it using in vitro methods represent a field of intense research.

In addition to quantitative risk assessment, potency information is also necessary as regulatory agencies require that sensitizers be classified into potency categories. The 2011 Globally Harmonized System of Classification and Labelling of Chemicals (GHS) edition introduced two subcategories for skin sensitizers (simply schematized in Fig. 3):

- Subcategory $1 \mathrm{~A}$ - strong skin sensitizers, for substances that occur frequently in humans and/or have high potency in animals;

- Subcategory 1B-“other" skin sensitizers, for substances that show low frequency of occurrence in humans and/or a low moderate potency in animals.

Skin sensitizers are classified as Category 1 when the relevant regulatory authority does not require subcategorization or when data are insufficient for subcategorization. Non-sensitizers are not classified (ICCVAM LLNA Potency Evaluation Report of 2011).

To provide such information, statistical models to predict skin sensitization potency for murine LLNA and human outcomes have also been proposed (Zang et al. 2017). As reported by Zang, based on in silico and in vitro methods, the best one-tiered model predicted LLNA outcomes with $78 \%$ accuracy, and human outcomes with $75 \%$ accuracy (LLNA predicts human potency categories with $69 \%$ accuracy). These methods may provide valuable information for assessing skin sensitization class of potency (e.g. strong and weak), but for quantitative risk assessment of skin sensitization a dose is required. Therefore, additional efforts are clearly needed both from a biological and regulatory point of view. International harmonization and standardization are needed to facilitate the translation of defined approaches into an international performance-based Test Guideline (Zang et al. 2017).

To conclude, a reduction of ACD can be achieved by a correct detection of skin sensitizers, characterization of potency, understanding of human skin exposure, and application of adequate risk assessment and management strategies. Only improved risk assessment, better education of risk assessors, better education of consumers on the proper use of products, and better marketing surveillance by authorities to control proper product safety evaluation could help to 'make contact allergy history'.

\section{References}

Aeby P, Python F, Goebel C (2007) Skin sensitization: understanding the in vivo situation for the development of reliable in vitro test approaches. ALTEX 24(Spec No):3-5. http://3r-training.tierv ersuch.ch/en/module_3r/sensitization_in-vitro/acd

Agren UM, Tammi RH, Tammi MI (1997) Reactive oxygen species contribute to epidermal hyaluronan catabolism in human skin organ culture. Free Radic Biol Med 23(7):996-1001. https://doi. org/10.1016/S0891-5849(97)00098-1

Akiba H, Kehren J, Ducluzeau MT, Krasteva M, Horand F, Kaiserlian D, Kaneko F, Nicolas JF (2002) Skin inflammation during contact hypersensitivity is mediated by early recruitment of CD8 $+\mathrm{T}$ cytotoxic 1 cells inducing keratinocyte apoptosis. J Immunol 168(6):3079-3087. https://doi.org/10.4049/jimmunol.168.6.3079

Alase A, Wittmann M (2012) Therapeutic strategies in allergic contact dermatitis. Recent Pat Inflamm Allergy Drug Discov 6(3):210 221. https://doi.org/10.2174/187221312802652794

Alloul-Ramdhani M, Tensen CP, El Ghalbzouri A (2014) Performance of the N/TERT epidermal model for skin sensitizer identification via Nrf2-Keap1-ARE pathway activation. Toxicol In Vitro 28(5):982-989. https://doi.org/10.1016/j.tiv.2014.04.007

Aptula AO, Roberts DW, Pease CK (2007) Haptens, prohaptens and prehaptens, or electrophiles and proelectrophiles. Contact Dermat 56(1):54-56. https://doi.org/10.1111/j.1600-0536.2007.00944.x

Averbeck M, Kuhn S, Bühligen J, Götte M, Simon JC, Polte T (2017) DC migration. Syndecan-1 regulates dendritic cell migration 
in cutaneous hypersensitivity to haptens. Exp Dermatol 26(11):1060-1067. https://doi.org/10.1111/exd.13374

Babina M, Guhl S, Artuc M, Zuberbier T (2016) IL-4 and human skin mast cells revisited: reinforcement of a pro-allergic phenotype upon prolonged exposure. Arch Dermatol Res 308(9):665-670. https://doi.org/10.1007/s00403-016-1688-x

Bajorath J (2000) Molecular organization, structural features, and ligand binding characteristics of $\mathrm{Cd} 44$, a highly variable cell surface glycoprotein with multiple functions. Proteins 39(2):103-111. https://doi.org/10.1002/(SICI)10970134(20000501)39:2\%3C103::AID-PROT1\%3E3.0.CO;2-G

Basketter DA, Kimber I (2009) Updating the skin sensitization in vitro data assessment paradigm in 2009. J Appl Toxicol 29(6):545-550. https://doi.org/10.1002/jat.1443

Basketter DA, Balikie L, Dearman RJ, Kimber I, Ryan CA, Gerberick GF, Harvey P, Evans P, White IR, Rycroft RJ (2000) Use of the local lymph node assay for the estimation of relative contact allergenic potency. Contact Dermat 42(6):344-348. https://doi.org/10.1034/j.1600-0536.2000.042006344.x

Bhatia S (2016) Natural polymer drug delivery systems: nanoparticles, plants, and algae. Springer International Publishing, Cham, pp 1-32

Bhoyar N, Giri TK, Tripathi DK, Alexander AA (2012) Recent advances in novel drug delivery system through gels: review. J Pharm Allied Health Sci 2:21-39. https://doi.org/10.3923/ jpahs.2012.21.39

Boukhman MP, Maibach HI (2001) Thresholds in contact sensitization: immunologic mechanisms and experimental evidence in humans-an overview. Food Chem Toxicol 39(12):1125-1134. https://doi.org/10.1016/S0278-6915(01)00062-X

Bourguignon LY (2014) Matrix hyaluronan-activated Cd44 signaling promotes keratinocyte activities and improves abnormal epidermal functions. Am J Pathol 184(7):1912-1919. https:// doi.org/10.1016/j.ajpath.2014.03.010

Boverhof DR, Billington R, Gollapudi BB, Hotchkiss JA, Krieger SM, Poole A, Wiescinski CM, Woolhiser MR (2008) Respiratory sensitization and allergy: current research approaches and needs. Toxicol Appl Pharmacol 226(1):1-13. https://doi. org/10.1016/j.taap.2007.10.008

Bryniarski K, Ptak W, Jayakumar A, Püllmann K, Caplan MJ, Chairoungdua A, Lu J, Adams BD, Sikora E, Nazimek K, Marquez S, Kleinstein SH, Sangwung P, Iwakiri Y, Delgato E, Redegeld F, Blokhuis BR, Wojcikowski J, Daniel AW, Groot Kormelink T, Askenase PW (2013) Antigen-specific, antibodycoated, exosome-like nanovesicles deliver suppressor T-cell microRNA-150 to effector T cells to inhibit contact sensitivity. J Allergy Clin Immunol 132(1):170-181. https://doi. org/10.1016/j.jaci.2013.04.048

Campo GM, Avenoso A, Campo S, D'Ascola A, Nastasi G, Calatroni A (2010) Small hyaluronan oligosaccharides induce inflammation by engaging both toll-like-4 and CD44 receptors in human chondrocytes. Biochem Pharmacol 80(4):480-490. https://doi. org/10.1016/j.bcp.2010.04.024

Casati S, Aschberger K, Barroso J, Casey W, Delgado I, Kim TS, Kleinstreuer N, Kojima H, Lee JK, Lowit A, Park HK, Régimbald-Krnel MJ, Strickland J, Whelan M, Yang Y, Zuang V (2018) Standardisation of defined approaches for skin sensitisation testing to support regulatory use and international adoption: position of the International Cooperation on Alternative Test Methods. Arch Toxicol 92(2):611-617. https://doi. org/10.1007/s00204-017-2097-4

Cavani A (2008) Immune regulatory mechanisms in allergic contact dermatitis and contact sensitization. Chem Immunol Allergy 94:93-100. https://doi.org/10.1159/000154934
Cavani A, De Pità O, Girolomoni G (2007) New aspects of the molecular basis of contact allergy. Curr Opin Allergy Clin Immunol 7(5):404-408. https://doi.org/10.1097/ACI.0b013e3282ef6923

Chen G, Qiu H, Prasad PN, Chen X (2014) Upconversion nanoparticles: design, nanochemistry, and applications in theranostics. Chem Rev 114:5161-5214. https://doi.org/10.1021/cr400425h

Coricovac DE, Moacă EA, Pinzaru I, Cîtu C, Soica C, Mihali CV, Păcurariu C, Tutelyan VA, Tsatsakis A, Dehelean CA (2017) Biocompatible colloidal suspensions based on magnetic iron oxide nanoparticles: synthesis, characterization and Toxicological profile. Front Pharmacol 8:154. https://doi.org/10.3389/fphar .2017 .00154

Corsini E, Mitjans M, Galbiati V, Lucchi L, Galli CL, Marinovich M (2009) Use of IL-18 production in a human keratinocyte cell line to discriminate contact sensitizers from irritants and low molecular weight respiratory allergens. Toxicol In Vitro 23(5):789-796. https://doi.org/10.1016/j.tiv.2009.04.005

Corsini E, Galbiati V, Nikitovic D, Tsatsakis AM (2013) Role of oxidative stress in chemical allergens induced skin cells activation. Food Chem Toxicol 61:74-81. https://doi.org/10.1016/j. fct.2013.02.038

Cottrez F, Boitel E, Ourlin JC, Peiffer JL, Fabre I, Henaoui IS, Mari B, Vallauri A, Paquet A, Barbry P, Auriault C, Aeby P, Groux H (2016) SENS-IS, a 3D reconstituted epidermis based model for quantifying chemical sensitization potency: reproducibility and predictivity results from an inter-laboratory study. Toxicol In Vitro 32:248-260. https://doi.org/10.1016/j.tiv.2016.01.007

Crosera M, Adami G, Mauro M, Bovenzi M, Baracchini E, Larese Filon F (2016) In vitro dermal penetration of nickel nanoparticles. Chemosphere 145:301-306. https://doi.org/10.1016/j. chemosphere.2015.11.076

Dhingra N, Shemer A, da Rosa JC, Rozenblit M, Fuentes-Duculan J, Gittler JK, Finney R, Czarnowicki T, Zheng X, Xu H, Estrada YD, Cardinale I, Suárez-Fariñas M, Krueger JG, GuttmanYassky E (2014) Molecular profiling of contact dermatitis skin identifies allergen-dependent differences in immune response. J Allergy Clin Immunol 134(2):362-372. https://doi.org/10.1016/j. jaci.2014.03.009

Döge N, Hadam S, Volz P, Wolf A, Schönborn KH, Blume-Peytavi U, Alexiev U, Vogt A (2018) Identification of polystyrene nanoparticle penetration across intact skin barrier as rare event at sites of focal particle aggregations. J Biophotonics 11(4):e201700169. https://doi.org/10.1002/jbio.201700169

dos Santos GG, Reinders J, Ouwehand K, Rustemeyer T, Scheper RJ, Gibbs S (2009) Progress on the development of human in vitro dendritic cell based assays for assessment of the sensitizing potential of a compound. Toxicol Appl Pharmacol 236(3):372382. https://doi.org/10.1016/j.taap.2009.02.004

Ebner S, Nguyen VA, Forstner M, Wang YH, Wolfram D, Liu YJ, Romani N (2007) Thymic stromal lymphopoietin converts human epidermal Langerhans cells into antigen-presenting cells that induce proallergic T cells. J Allergy Clin Immunol 119(4):982990. https://doi.org/10.1016/j.jaci.2007.01.003

Ehling S, Roßbach K, Dunston SM, Stark H, Bäumer W (2016) Allergic inflammation is augmented via histamine $\mathrm{H} 4$ receptor activation: the role of natural killer cells in vitro and in vivo. J Dermatol Sci 83(2):106-115. https://doi.org/10.1016/j.jderm sci.2016.04.011

Esser PR, Wolfle U, Durr C, von Loewenich FD, Schempp CM, Freudenberg MA, Jakob T, Martin SF (2012) Contact sensitizers induce skin inflammation via ROS production and hyaluronic acid degradation. PLoS One 7(7):e41340. https://doi. org/10.1371/journal.pone.0041340

Esser PR, Kimber I, Martin SF (2014) Correlation of contact sensitizer potency with $\mathrm{T}$ cell frequency and TCR repertoire diversity. EXS 104:101-114. https://doi.org/10.1007/978-3-0348-0726-5_8 
Ezendam J, Bokkers BGH, Bil W, Delmaar JE (2018) Skin sensitization quantitative risk assessment (QRA) based on aggregate dermal exposure to methylisothiazolinone in personal care and household cleaning products. Food Chem Toxicol 112:242250. https://doi.org/10.1016/j.fct.2017.12.054

Freudenberg MA, Esser PR, Jakob T, Galanos C, Martin SF (2009) Innate and adaptive immune responses in contact dermatitis: analogy with infections. G Ital Dermatol Venereol 144(2):173-185

Friedmann PS, Pickard C (2014) Contact hypersensitivity: quantitative aspects, susceptibility and risk factors. EXS 104:51-71. https://doi.org/10.1007/978-3-0348-0726-5_5

Friedmann PS, Moss C, Shuster S, Simpson JS (1983) Quantitative relationship between sensitizing dose of DNCB and reactivity in normal subjects. Clin Exp Immunol 53:709-715

Frombach J, Sonnenburg A, Krapohl BD, Zuberbier T, Stahlmann $\mathrm{R}$, Schreiner M (2017) A novel method to generate monocytederived dendritic cells during coculture with $\mathrm{HaCaT}$ facilitates detection of weak contact allergens in cosmetics. Arch Toxicol 91(1):339-350. https://doi.org/10.1007/s00204-016-1722-y

Gaide O, Emerson RO, Jiang X, Gulati N, Nizza S, Desmarais C, Robins H, Krueger JG, Clark RA, Kupper TS (2015) Common clonal origin of central and resident memory $\mathrm{T}$ cells following skin immunization. Nat Med 21(6):647-653. https://doi. org/10.1038/nm.3860

Galbiati V, Corsini E (2012) The NCTC 2544 IL-18 assay for the in vitro identification of contact allergens. Curr Protoc Toxicol. https://doi.org/10.1002/0471140856.tx2008s54

Galbiati V, Carne A, Mitjans M, Galli CL, Marinovich M, Corsini E (2012) Isoeugenol destabilizes IL-8 mRNA expression in THP-1 cells through induction of the negative regulator of mRNA stability tristetraprolin. Arch Toxicol 86(2):239-248. https://doi.org/10.1007/s00204-011-0758-2

Galbiati V, Cornaghi L, Gianazza E, Potenza MA, Donetti E, Marinovich M, Corsini E (2018) In vitro assessment of silver nanoparticles immunotoxicity. Food Chem Toxicol 112:363374. https://doi.org/10.1016/j.fct.2017.12.023

Galli SJ, Tsai M (2012) IgE and mast cells in allergic disease. Nat Med 18(5):693-704. https://doi.org/10.1038/nm.2755

Gerberick GF, Robinson MK (2000) Skin sensitization risk assessment of new products. Am J Contact Dermat 11:65-73

Gerberick GF, Sikorski EE (1998) In vitro and in vivo testing techniques for allergic contact dermatitis. Am J Contact Dermat 9(2):111-118

Gerberick GF, Vassallo JD, Foertsch LM, Price BB, Chaney JG, Lepoittevin JP (2007) Quantification of chemical peptide reactivity for screening contact allergens: a classification tree model approach. Toxicol Sci 97(2):417-427. https://doi. org/10.1093/toxsci/kfm064

Gibbs S, Corsini E, Spiekstra SW, Galbiati V, Fuchs HW, Degeorge G, Troese M, Hayden P, Deng W, Roggen E (2013) An epidermal equivalent assay for identification and ranking potency of contact sensitizers. Toxicol Appl Pharmacol 272(2):529-541. https://doi.org/10.1016/j.taap.2013.07.003

Gimenez-Rivera VA, Siebenhaar F, Zimmermann C, Siiskonen H, Metz M, Maurer M (2016) Mast cells limit the exacerbation of chronic allergic contact dermatitis in response to repeated allergen exposure. J Immunol 197(11):4240-4246. https://doi. org/10.4049/jimmunol.1600236

Girolomoni G, Gisondi P, Ottaviani C, Cavani A (2004) Immunoregulation of allergic contact dermatitis. Eur J Dermatol 31(4):264-270. https://doi.org/10.1111/j.1346-8138.2004. tb00671.x

Gober MD, Gaspari AA (2008) Allergic contact dermatitis. Curr Dir Autoimmun 10:1-26. https://doi.org/10.1159/000131410
Goldberg M, Langer R, Jia X (2007) Nanostructured materials for applications in drug delivery and tissue engineering. J Biomater Sci Polym Ed 18:241-268

Gorbachev AV, Fairchild RL (2004) CD4 + T cells regulate CD8 + T cell-mediated cutaneous immune responses by restricting effector T cell development through a Fas ligand-dependent mechanism. J Immunol 172(4):2286-2295. https://doi.org/10.4049/jimmu nol.172.4.2286

Guyard-Nicodème M, Gerault E, Platteel M, Peschard O, Veron W, Mondon P, Pascal S, Feuilloley MG. Development of a multiparametric in vitro model of skin sensitization (2015) J Appl Toxicol 35(1):48-58. https://doi.org/10.1002/jat.2986

He D, Wu L, Kim HK, Li H, Elmets CA, Xu H (2009) IL-17 and IFN-gamma mediate the elicitation of contact hypersensitivity responses by different mechanisms and both are required for optimal responses. J Immunol 183(2):1463-1470. https://doi. org/10.4049/jimmunol.0804108

Hirai T, Yoshioka Y, Takahashi H, Ichihashi K, Udaka A, Mori T, Nishijima N, Yoshida T, Nagano K, Kamada H, Tsunoda S, Takagi T, Ishii KJ, Nabeshi H, Yoshikawa T, Higashisaka K, Tsutsumi Y (2015) Cutaneous exposure to agglomerates of silica nanoparticles and allergen results in IgE-biased immune response and increased sensitivity to anaphylaxis in mice. Part Fibre Toxicol 12:16. https://doi.org/10.1186/s12989-015-0095-3

Hoyne GF, Lamb JR (1997) Regulation of T cell function in mucosal tolerance. Immunol Cell Biol 75:197-201. https://doi. org/10.1038/icb.1997.29

Ilves M, Palomäki J, Vippola M, Lehto M, Savolainen K, Savinko T, Alenius H (2014) Topically applied $\mathrm{ZnO}$ nanoparticles suppress allergen induced skin inflammation but induce vigorous IgE production in the atopic dermatitis mouse model. Part Fibre Toxicol 11:38. https://doi.org/10.1186/s12989-014-0038-4

Ishiwatari S, Suzuki T, Hitomi T, Yoshino S, Matsukuma T, Tsuji T (2007) Effects of methyl paraben on skin keratinocytes. J Appl Toxicol 27(1):1-9. https://doi.org/10.1002/jat.1176

Jäckh C, Fabian E, van Ravenzwaay B, Landsiedel R (2012) Relevance of xenobiotic enzymes in human skin in vitro models to activate pro-sensitizers. J Immunotoxicol 9(4):426-438. https://doi. org/10.3109/1547691X.2012.664578

Jawdat DM, Albert EJ, Rowden G, Haidl ID, Marshall JS (2004) IgEmediated mast cell activation induces Langerhans cell migration in vivo. J Immunol 173(8):5275-5282. https://doi.org/10.4049/ jimmunol.173.8.5275

Jin H, Kumar L, Mathias C, Zurakowski D, Oettgen H, Gorelik L, Geha R (2009) Toll-like receptor 2 is important for the $T(H) 1$ response to cutaneous sensitization. J Allergy Clin Immunol 123(4):875-882. https://doi.org/10.1016/j.jaci.2009.02.007 e1.

Karlberg AT, Bergström MA, Börje A, Luthman K, Nilsson JL (2008) Allergic contact dermatitis-formation, structural requirements, and reactivity of skin sensitizers. Chem Res Toxicol 21(1):53-69. https://doi.org/10.1021/tx7002239

Karschuk N, Tepe Y, Gerlach S, Pape W, Wenck H, Schmucker R, Wittern KP, Schepky A, Reuter H (2010) A novel in vitro method for the detection and characterization of photosensitizers. PLoS One 5(12):e15221. https://doi.org/10.1371/journal.pone.0015221

Kavasi RM, Berdiaki A, Spyridaki I, Corsini E, Tsatsakis A, Tzanakakis G, Nikitovic D (2017) HA metabolism in skin homeostasis and inflammatory disease. Food Chem Toxicol 101:128-138. https://doi.org/10.1016/j.fct.2017.01.012

Kim Y, Lee YS, Hahn JH, Choe J, Kwon HJ, Ro JY, Jeoung D (2008) Hyaluronic acid targets CD44 and inhibits FceRI signaling involving PKCdelta, Rac1, ROS, and MAPK to exert anti-allergic effect. Mol Immunol 45(9):2537-2547. https://doi.org/10.1016/j. molimm.2008.01.008

Kimber I, Pallardy M (2014) The use of T cells in hazard characterization of chemical and drug allergens and integration 
in testing strategies foreword. EXS 104:1-7. https://doi. org/10.1007/978-3-0348-0726-5 1

Kimber I, Gerberick GF, Basketter DA (1999) Thresholds in contact sensitization: theoretical and practical considerations. Food Chem Toxicol 37(5):553-560. https://doi.org/10.1016/S0278 $-6915(99) 00048-4$

Kimber I, Basketter DA, Butler M, Gamer A, Garrigue JL, Gerberick GF, Newsome C, Steiling W, Vohr HW (2003) Classification of contact allergens according to potency: proposals. Food Chem Toxicol 41(12):1799-1809. https://doi.org/10.1016/S0278 $-6915(03) 00223-0$

Kindas-Mugge I, Trautinger F (1994) Increased expression of the M(R) 27,000 heat shock protein (Hsp27) in in vitro differentiated normal human keratinocytes. Cell Growth Differ 5(7):777-781

Kish DD, Gorbachev AV, Fairchild RL (2012) IL-1 receptor signaling is required at multiple stages of sensitization and elicitation of the contact hypersensitivity response. J Immunol 188(4):17611771. https://doi.org/10.4049/jimmunol.1100928

Klekotka PA, Yang L, Yokoyama WM (2010) Contrasting roles of the IL-1 and IL-18 receptors in MyD88-dependent contact hypersensitivity. J Investig Dermatol 130(1):184-191. https://doi. org/10.1038/jid.2009.242

Kolesaric A, Stingl G, Elbe-Bürger A (1997) MHC class I +/II - dendritic cells induce hapten-specific immune responses in vitro and in vivo. J Investig Dermatol 109(4):580-585. https://doi. org/10.1111/1523-1747.ep12337508

Koppes SA, Engebretsen KA, Agner T, Angelova-Fischer I, Berents T, Brandner J, Brans R, Clausen ML, Hummler E, Jakasa I, JurakićTončic R, John SM, Khnykin D, Molin S, Holm JO, Suomela S, Thierse HJ, Kezic S, Martin SF, Thyssen JP (2017) Current knowledge on biomarkers for contact sensitization and allergic contact dermatitis. Contact Dermat 77(1):1-16. https://doi. org/10.1111/cod.12789

Krasteva M, Kehren J, Horand F, Akiba H, Choquet G, Ducluzeau MT, Tédone R, Garrigue JL, Kaiserlian D, Nicolas JF (1998) Dual role of dendritic cells in the induction and down-regulation of antigen-specific cutaneous inflammation. J Immunol 160(3):1181-1190

Kraus LF, Scheurmann N, Frenzel DF, Tasdogan A, Weiss JM (2018) 9-cis-Retinoic acid induces a distinct regulatory dendritic cell phenotype that modulates murine delayed-type allergy. Contact Dermat 78(1):41-54. https://doi.org/10.1111/cod.12868

Krieg T, Aumailley M (2011) The extracellular matrix of the dermis: flexible structures with dynamic functions. Exp Dermatol 20(8):689-695. https://doi.org/10.1111/j.1600-0625.2011.01313 . $\mathrm{x}$

Kuskov AN, Kulikov PP, Shtilman MI, Rakitskii VN, Tsatsakis AM (2016) Amphiphilic poly- $N$-vynilpyrrolidone nanoparticles: cytotoxicity and acute toxicity study. Food Chem Toxicol 96:273-279. https://doi.org/10.1016/j.fct.2016.08.017

Kuskov AN, Kulikov PP, Goryachaya AV, Tzatzarakis MN, Docea AO, Velonia K, Shtilman MI, Tsatsakis AM (2017) Amphiphilic poly$N$-vinylpyrrolidone nanoparticles as carriers for non-steroidal anti-inflammatory drugs: in vitro cytotoxicity and in vivo acute toxicity study. Nanomedicine 13(3):1021-1030. https://doi. org/10.1016/j.nano.2016.11.006

Lehé CL, Jacobs JJ, Elliott GR, Das PK (2003) A two-centre evaluation of the human organotypic skin explant culture model for screening contact allergens. Altern Lab Anim 31(6):553-561

Lehé CL, Jacobs JJ, Hua CM, Courtellemont P, Elliott GR, Das PK (2006) Subtoxic concentrations of allergenic haptens induce LC migration and maturation in a human organotypic skin explant culture model: a novel method for identifying potential contact allergens. Exp Dermatol 15(6):421-431. https://doi.org/10.111 1/j.0906-6705.2006.00415.x
Lepoittevin JP (1999) Development of structure-activity relationships (SARs) in allergic contact dermatitis. Cell Biol Toxicol 15(1):47-55. https://doi.org/10.1023/A:1007502723275

Lepoittevin JP (2006) Metabolism versus chemical transformation or pro- versus prehaptens? Contact Dermat 54(2):73-74. https://doi. org/10.1111/j.0105-1873.2006.00795.x

Liaw L, Skinner MP, Raines EW, Ross R, Cheresh DA, Schwartz SM, Giachelli CM (1995) The adhesive and migratory effects of osteopontin are mediated via distinct cell surface integrins. Role of alpha v beta 3 in smooth muscle cell migration to osteopontin in vitro. J Clin Investig 95:713-724. https://doi.org/10.1172/ JCI117718

Liu YJ, Soumelis V, Watanabe N, Ito T, Wang YH, de Waal Malefyt R, Omori M, Zhou B, Ziegler SF (2007) TSLP: an epithelial cell cytokine that regulates $\mathrm{T}$ cell differentiation by conditioning dendritic cell maturation. Annu Rev Immunol 25:193-219. https ://doi.org/10.1172/JCI117718

Liu B, Escalera J, Balakrishna S, Fan L, Caceres AI, Robinson E, Sui A, McKay MC, McAlexander MA, Herrick CA, Jordt SE (2013) TRPA1 controls inflammation and pruritogen responses in allergic contact dermatitis. FASEB J 27(9):3549-3563. https ://doi.org/10.1096/fj.13-229948

Loser K, Mehling A, Loeser S, Apelt J, Kuhn A, Grabbe S, Schwarz T, Penninger JM, Beissert S (2006) Epidermal RANKL controls regulatory T-cell numbers via activation of dendritic cells. Nat Med 12(12):1372-1379. https://doi.org/10.1038/nm1518

Loveless SE, Api AM, Crevel RW, Debruyne E, Gamer A, Jowsey IR, Kern P, Kimber I, Lea L, Lloyd P, Mehmood Z, Steiling W, Veenstra G, Woolhiser M, Hennes C (2010) Potency values from the local lymph node assay: application to classification, labelling and risk assessment. Regul Toxicol Pharmacol 56(1):54-66. https://doi.org/10.1016/j.jaci.2012.06.022

Luckey U, Schmidt T, Pfender N, Romer M, Lorenz N, Martin SF, Bopp T, Schmitt E, Nikolaev A, Yogev N, Waisman A, Jakob T, Steinbrink K (2012) Crosstalk of regulatory T cells and tolerogenic dendritic cells prevents contact allergy in subjects with low zone tolerance. J Allergy Clin Immunol 130(3):781-797. https:// doi.org/10.1016/j.jaci.2012.06.022

Malaisse J, Bourguignon V, De Vuyst E, De Rouvroit CL, Nikkels AF, Flamion B, Poumay Y (2014) Hyaluronan metabolism in human keratinocytes and atopic dermatitis skin is driven by a balance of hyaluronan synthases 1 and 3. J Investig Dermatol 134(8):2174-2182. https://doi.org/10.1074/jbc.M115.661348

Malaisse J, Pendaries V, Hontoir F, De Glas V, Van Vlaender D, Simon M, Lambert de Rouvroit C, Poumay Y, Flamion B (2016) Hyaluronan does not regulate human epidermal keratinocyte proliferation and differentiation. J Biol Chem 291(12):6347-6358. https ://doi.org/10.1074/jbc.M115.661348

Mannucci C, Casciaro M, Minciullo PL, Calapai G, Navarra M, Gangemi S (2017) Involvement of microRNAs in skin disorders: a literature review. Allergy Asthma Proc 38(1):9-15. https://doi. org/10.2500/aap.2017.38.4013

Martin SF (2012) Allergic contact dermatitis: xenoinflammation of the skin. Curr Opin Immunol 24(6):720-729. https://doi. org/10.1016/j.coi.2012.08.003

Martin SF, Dudda JC, Bachtanian E, Lembo A, Liller S, Durr C, Heimesaat MM, Bereswill S, Fejer G, Vassileva R, Jakob T, Freudenberg N, Termeer CC, Johner C, Galanos C, Freudenberg MA (2008) Toll-like receptor and IL-12 signaling control susceptibility to contact hypersensitivity. J Exp Med 205(9):2151-2162. https://doi.org/10.1084/jem.20070509

Martin SF, Esser PR, Weber FC, Jakob T, Freudenberg MA, Schmidt M, Goebeler M (2011) Mechanisms of chemical-induced innate immunity in allergic contact dermatitis. Allergy 66(9):11521163. https://doi.org/10.1111/j.1398-9995.2011.02652.x 
Martinon F, Mayor A, Tschopp J (2009) The inflammasomes: guardians of the body. Annu Rev Immunol 27:229-265. https://doi. org/10.1146/annurev.immunol.021908.132715

Maurer M, Seidel-Guyenot W, Metz M, Knop J, Steinbrink K (2003) Critical role of IL-10 in the induction of low zone tolerance to contact allergens. J Clin Investig 112(3):432-439. https://doi. org/10.1172/JCI200318106

McFadden JP, Puangpet P, Basketter DA, Dearman RJ, Kimber I (2013) Why does allergic contact dermatitis exist? Br J Dermatol 168(4):692-699. https://doi.org/10.1111/bjd.12145

McKim JM Jr, Keller DJ 3rd, Gorski JR (2012) An in vitro method for detecting chemical sensitization using human reconstructed skin models and its applicability to cosmetic, pharmaceutical and medical device safety testing. Cutan Ocul Toxicol 31(4):292-305. https://doi.org/10.3109/15569527.2012.66703 1

McMillan JR, Akiyama M, Shimizu H (2003) Epidermal basement membrane zone components: ultrastructural distribution and molecular interactions. J Dermatol Sci 31(3):169-177. https:// doi.org/10.1016/S0923-1811(03)00045-8

Meller S, Lauerma AI, Kopp FM, Winterberg F, Anthoni M, Müller A, Gombert M, Haahtela A, Alenius H, Rieker J, Dieu-Nosjean MC, Kubitza RC, Gleichmann E, Ruzicka T, Zlotnik A, Homey B (2007) Chemokine responses distinguish chemical-induced allergic from irritant skin inflammation: memory $\mathrm{T}$ cells make the difference. J Allergy Clin Immunol 119(6):1470-1480. https ://doi.org/10.1016/j.jaci.2006.12.654

Meyer LJ, Stern R (1994) Age-dependent changes of hyaluronan in human skin. J Investig Dermatol 102(3):385-389. https://doi. org/10.1111/1523-1747.ep12371800

Mocellin S, Panelli MC, Wang E, Nagorsen D, Marincola FM (2003) The dual role of IL-10. Trends Immunol 24(1):36-43. https://doi. org/10.1016/S1471-4906(02)00009-1

Monzon ME, Fregien N, Schmid N, Falcon NS, Campos M, CasalinoMatsuda SM, Forteza RM (2010) Reactive oxygen species and hyaluronidase 2 regulate airway epithelial hyaluronan fragmentation. J Biol Chem 285(34):26126-26134. https://doi.org/10.1074/ jbc.M110.135194

Mueller MM, Fusenig NE (2004) Friends or foes-bipolar effects of the tumour stroma in cancer. Nat Rev Cancer 4(11):839-849. https://doi.org/10.1038/nrc1477

Muto J, Morioka Y, Yamasaki K, Kim M, Garcia A, Carlin AF, Varki A, Gallo RL (2014) Hyaluronan digestion controls DC migration from the skin. J Clin Investig 124(3):1309-1319. https://doi. org/10.1172/JCI67947

Mutschler J, Giménez-Arnau E, Foertsch L, Gerberick GF, Lepoittevin JP (2009) Mechanistic assessment of peptide reactivity assay to predict skin allergens with Kathon CG isothiazolinones. Toxicol In Vitro 23(3):439-446. https://doi.org/10.1016/j.tiv.2009.01.014

Nakamura N, Tamagawa-Mineoka R, Ueta M, Kinoshita S, Katoh N (2015) Toll-like receptor 3 increases allergic and irritant contact dermatitis. J Investig Dermatol 135(2):411-417. https://doi. org/10.1038/jid.2014.402

Nakao M, Sugaya M, Takahashi N, Otobe S, Nakajima R, Oka T, Kabasawa M, Suga H, Morimura S, Miyagaki T, Fujita H, Asano Y, Sato S (2016) Increased syndecan-4 expression in sera and skin of patients with atopic dermatitis. Arch Dermatol Res 308(9):655-660. https://doi.org/10.1007/s00403-016-1683-2

Nazimek K, Bryniarski K, Askenase PW (2016) Functions of exosomes and microbial extracellular vesicles in allergy and contact and delayed-type hypersensitivity. Int Arch Allergy Immunol 171(1):1-26. https://doi.org/10.1159/000449249

Neagu M, Piperigkou Z, Karamanou K, Engin AB, Docea AO, Constantin C, Negrei C, Nikitovic D, Tsatsakis A (2017) Protein biocorona: critical issue in immune nanotoxicology. Arch Toxicol 91(3):1031-1048. https://doi.org/10.1007/s00204-016-1797-5
Neill T, Schaefer L, Iozzo RV (2015) Decoding the matrix: instructive roles of proteoglycan receptors. Biochemistry 54(30):4583-4598. https://doi.org/10.1021/acs.biochem.5b00653

Nikitovic D, Aggelidakis J, Young MF, Iozzo RV, Karamanos NK, Tzanakakis GN (2012) The biology of small leucine-rich proteoglycans in bone pathophysiology. J Biol Chem 287(41):3392633933. https://doi.org/10.1074/jbc.R112.379602

Nikitovic D, Corsini E, Kouretas D, Tsatsakis A, Tzanakakis G (2013) ROS-major mediators of extracellular matrix remodeling during tumor progression. Food Chem Toxicol 61:178-186. https://doi. org/10.1016/j.fct.2013.06.013

Nikitovic D, Mytilinaiou M, Berdiaki A, Karamanos NK, Tzanakakis GN (2014) Heparan sulfate proteoglycans and heparin regulate melanoma cell functions. Biochim Biophys Acta 1840(8):24712481. https://doi.org/10.1016/j.bbagen.2014.01.031

Nikitovic D, Berdiaki A, Galbiati V, Kavasi RM, Papale A, Tsatsakis A, Tzanakakis GN, Corsini E (2015) Hyaluronan regulates chemical allergen-induced IL-18 production in human keratinocytes. Toxicol Lett 232(1):89-97. https://doi.org/10.1016/j.toxle t.2014.09.026

Noble PW (2002) Hyaluronan and its catabolic products in tissue injury and repair. Matrix Biol 21(1):25-29. https://doi.org/10.1016/ S0945-053X(01)00184-6

Nosbaum A, Vocanson M, Rozieres A, Hennino A, Nicolas JF (2009) Allergic and irritant contact dermatitis. Eur J Dermatol 19(4):325-332. https://doi.org/10.1684/ejd.2009.0686

Nukada Y, Miyazawa M, Kazutoshi S, Sakaguchi H, Nishiyama N (2013) Data integration of non-animal tests for the development of a test battery to predict the skin sensitizing potential and potency of chemicals. Toxicol In Vitro 27(2):609-618. https:// doi.org/10.1016/j.tiv.2012.11.006

O'Regan AW, Chupp GL, Lowry JA, Goetschkes M, Mulligan N, Berman JS (1999) Osteopontin is associated with T cells in sarcoid granulomas and has T cell adhesive and cytokine-like properties in vitro. J Immunol 162(2):1024-1031

Oakes T, Heather JM, Best K, Byng-Maddick R, Husovsky C, Ismail M, Joshi K, Maxwell G, Noursadeghi M, Riddell N, Ruehl T, Turner CT, Uddin I, Chain B (2017) Quantitative characterization of the $\mathrm{T}$ cell receptor repertoire of naïve and memory subsets using an integrated experimental and computational pipeline which is robust, economical and versatile. Front Immunol 8:1267. https://doi.org/10.3389/fimmu.2017.01267

OECD (2014) The adverse outcome pathway for skin sensitisation initiated by covalent binding to proteins. OECD Publishing, Paris. https://doi.org/10.1787/9789264221444-en

Oesch F, Fabian E, Landsiedel R (2018) Xenobiotica-metabolizing enzymes in the skin of rat, mouse, pig, guinea pig, man, and in human skin models. Arch Toxicol 92(8):2411-2456. https://doi. org/10.1007/s00204-018-2232-x

Ohno S, Drummen GP, Kuroda M (2016) Focus on extracellular vesicles: development of extracellular vesicle-based therapeutic systems. Int J Mol Sci 17(2):172. https://doi.org/10.3390/ijms1 7020172

Ohtani T, Memezawa A, Okuyama R, Sayo T, Sugiyama Y, Inoue S, Aiba S (2009) Increased hyaluronan production and decreased E-cadherin expression by cytokine-stimulated keratinocytes lead to spongiosis formation. J Investig Dermatol 129(6):1412-1420. https://doi.org/10.1038/jid.2008.394

Ohtsu H, Seike M (2017) Histamine and histamine receptors in allergic dermatitis. Handb Exp Pharmacol 241:333-345. https://doi. org/10.1007/164_2016_9

Pinzaru I, Coricovac D, Dehelean C, Moacă EA, Mioc M, Baderca F, Sizemore I, Brittle S, Marti D, Calina CD, Tsatsakis AM, Şoica C (2018) Stable PEG-coated silver nanoparticles-a comprehensive toxicological profile. Food Chem Toxicol 111:546-556. https://doi.org/10.1016/j.fct.2017.11.051 
Piperigkou Z, Karamanou K, Engin AB, Gialeli C, Docea AO, Vynios DH, Pavão MS, Golokhvast KS, Shtilman MI, Argiris A, Shishatskaya E, Tsatsakis AM (2016) Emerging aspects of nanotoxicology in health and disease: from agriculture and food sector to cancer therapeutics. Food Chem Toxicol 91:42-57. https://doi. org/10.1016/j.fct.2016.03.003

Pistoor FH, Rambukkana A, Kroezen M, Lepoittevin JP, Bos JD, Kapsenberg ML, Ramadan Q, Ting FC (2016) In vitro microphysiological immune-competent model of the human skin. Lab Chip 16(10):1899-1908. https://doi.org/10.1039/c6lc00229c

Potter TM, Neun BW, Dobrovolskaia MA (2018) In vitro and in vivo methods for analysis of nanoparticle potential to induce delayedtype hypersensitivity reactions. Methods Mol Biol 1682:197210. https://doi.org/10.1007/978-1-4939-7352-1_17

Pozzi A, Yurchenco PD, Iozzo RV (2017) The nature and biology of basement membranes. Matrix Biol 57-58:1-11. https://doi. org/10.1016/j.matbio.2016.12.009

Ptak W, Nazimek K, Askenase PW, Bryniarski K (2015) From mysterious supernatant entity to miRNA-150 in antigen-specific exosomes: a history of hapten-specific $\mathrm{T}$ suppressor factor. Arch Immunol Ther Exp (Warsz) 63(5):345-356. https://doi. org/10.1007/s00005-015-0331-4

Ramadan Q, Ting FC (2016) In vitro micro-physiological immunecompetent model of the human skin. Lab Chip 16(10):18991908. https://doi.org/10.1039/c6lc00229c

Rambukkana A, Pistoor FH, Bos JD, Kapsenberg ML, Das PK (1996) Effects of contact allergens on human Langerhans cells in skin organ culture: migration, modulation of cell surface molecules, and early expression of interleukin-1 beta protein. Lab Investig J Tech Methods Pathol 74(2):422-436

Rancan F, Gao Q, Graf C, Troppens S, Hadam S, Hackbarth S, Kembuan C, Blume-Peytavi U, Rühl E, Lademann J, Vogt A (2012) Skin penetration and cellular uptake of amorphous silica nanoparticles with variable size, surface functionalization, and colloidal stability. ACS Nano 6(8):6829-6842. https://doi.org/10.1021/ $\mathrm{nn} 301622 \mathrm{~h}$

REACH (2006) Regulation (EC) No 1907/2006 of the european parliament and of the Council of 18 December 2006 concerning the registration, evaluation, authorisation and restriction of chemicals (REACH), and its guidance documents; available at: http:// eurlex.europa.eu/LexUriServ/LexUriServ.do\%3Furi=OJ:L:20 06:396:0001:0849:EN:PDF, and at: http://guidance.echa.europ a.eu/docs/guidance_document/information_requirements_en.htm

Reduta T, Śniecińska M, Pawłoś A, Sulkiewicz A, Sokołowska M (2015) Serum osteopontin levels in disseminated allergic contact dermatitis. Adv Med Sci 60(2):273-276. https://doi. org/10.1016/j.advms.2015.05.001

Rees JL, Friedmann PS, Matthews JN (1990) The influence of area of application on sensitization by dinitrochlorobenzene. Br J Dermatol 122:29-31. https://doi.org/10.1111/j.1365-2133.1990. tb08236.x

Robinson NA, LaCelle PT, Eckert RL (1996) Involucrin is a covalently crosslinked constituent of highly purified epidermal corneocytes: evidence for a common pattern of involucrin crosslinking in vivo and in vitro. J Investig Dermatol 107(1):101-107

Robinson MK, Gerberick GF, Ryan CA, McNamee P, White I, Basketter DA (2000) The importance of exposure in the assessment of skin sensitization risk. Contact Dermat 42:251-259. https://doi. org/10.1034/j.1600-0536.2000.042005251.x

Rustemeyer T, Preuss M, von Blomberg BM, Das PK, Scheper RJ (2003) Comparison of two in vitro dendritic cell maturation models for screening contact sensitizers using a panel of methacrylates. Exp Dermatol 12(5):682-691. https://doi.org/10.103 4/j.1600-0625.2003.00077.x
Saint-Mezard P, Berard F, Dubois B, Kaiserlian D, Nicolas JF (2004) The role of CD4 + and CD8 + T cells in contact hypersensitivity and allergic contact dermatitis. Eur J Dermatol 14(3):131-138

Sakaguchi H, Ashikaga T, Miyazawa M, Yoshida Y, Ito Y, Yoneyama K, Hirota M, Itagaki H, Toyoda H, Suzuki H (2006) Development of an in vitro skin sensitization test using human cell lines; human Cell Line Activation Test (h-CLAT). II. An inter-laboratory study of the h-CLAT. Toxicol In Vitro 20(5):774-784. https ://doi.org/10.1016/j.tiv.2005.10.014

Salamon P, Shefler I, Hershko AY, Mekori YA (2016) The involvement of protein kinase D in T cell-induced mast cell activation. Int Arch Allergy Immunol 171(3-4):203-208. https://doi. org/10.1159/000452625

Sayo T, Sugiyama Y, Takahashi Y, Ozawa N, Sakai S, Ishikawa O, Tamura M, Inoue S (2002) Hyaluronan synthase 3 regulates hyaluronan synthesis in cultured human keratinocytes. J Investig Dermatol 118(1):43-48. https://doi.org/10.1046/j.0022202x.2001.01613.x

Schaefer L (2014) Complexity of danger: the diverse nature of damage-associated molecular patterns. J Biol Chem 289(51):3523735245. https://doi.org/10.1074/jbc.R114.619304

Seidel-Guyenot W, Alt R, Perschon S, Knop J, Steinbrink K (2004) B cells are not required for $\mathrm{T}$ cell priming in low zone tolerance to contact allergens and contact hypersensitivity. Eur J Immunol 34(11):3082-3090. https://doi.org/10.1002/eji.200425402

Shao M, Hussain Z, Thu HE, Khan S, Katas H, Ahmed TA, Tripathy M, Leng J, Qin HL, Bukhari SNA (2016) Drug nanocarrier, the future of atopic diseases: advanced drug delivery systems and smart management of disease. Colloids Surf B Biointerfaces 147:475-491. https://doi.org/10.1016/j.colsurfb.2016.08.027

Sher I, Zisman-Rozen S, Eliahu L, Whitelock JM, Maas-Szabowski N, Yamada Y, Breitkreutz D, Fusenig NE, Arikawa-Hirasawa E, Iozzo RV, Bergman R, Ron D (2006) Targeting perlecan in human keratinocytes reveals novel roles for perlecan in epidermal formation. J Biol Chem 281(8):5178-5187. https://doi. org/10.1074/jbc.M509500200

Shin JW, Choi YJ, Choi HR, Na JI, Kim KH, Park IA, Lee HS, Park KC (2015) Defective basement membrane in atopic dermatitis and possible role of IL-13. Eur Acad Dermatol Venereol 29(10):2060-2062. https://doi.org/10.1111/jdv.12596

Sloane JA, Blitz D, Margolin Z, Vartanian T (2010) A clear and present danger: endogenous ligands of Toll-like receptors. Neuromol Med 12(2):149-163. https://doi.org/10.1007/s12017-009-8094-x

Smulders S, Golanski L, Smolders E, Vanoirbeek J, Hoet PH (2015) Nano- $\mathrm{TiO}_{2}$ modulates the dermal sensitization potency of dinitrochlorobenzene after topical exposure. Br J Dermatol 172(2):392399. https://doi.org/10.1111/bjd.13295

Soumelis V, Reche PA, Kanzler H, Yuan W, Edward G, Homey B, Gilliet M, Ho S, Antonenko S, Lauerma A, Smith K, Gorman D, Zurawski S, Abrams J, Menon S, McClanahan T, de WaalMalefyt Rd R, Bazan F, Kastelein RA, Liu YJ (2002) Human epithelial cells trigger dendritic cell mediated allergic inflammation by producing TSLP. Nat Immunol 3(7):673-680. https:// doi.org/10.1038/ni805

Steinbrink K, Sorg C, Macher E (1996) Low zone tolerance to contact allergens in mice: a functional role for $\mathrm{CD} 8+\mathrm{T}$ helper type 2 cells. J Exp Med 183(3):759-768. https://doi.org/10.1084/ jem.183.3.759

Stern R, Maibach HI (2008) Hyaluronan in skin: aspects of aging and its pharmacologic modulation. Clin Dermatol 26(2):106-122. https://doi.org/10.1016/j.clindermatol.2007.09.013

Stern R, Asari AA, Sugahara KN (2006) Hyaluronan fragments: an information-rich system. Eur J Cell Biol 85(8):699-715. https:// doi.org/10.1016/j.ejcb.2006.05.009 
Stratum corneum DH, Igyártó BZ, Gaspari AA (2012) Early immune events in the induction of allergic contact dermatitis. Nat Rev Immunol 12(2):114-124. https://doi.org/10.1038/nri3150

Strickland J, Zang Q, Kleinstreuer N, Paris M, Lehmann DM, Choksi N, Matheson J, Jacobs A, Lowit A, Allen D, Casey W (2016) Integrated decision strategies for skin sensitization hazard. J Appl Toxicol 36(9):1150-1162. https://doi.org/10.1002/jat.3281

Strickland J, Zang Q, Kleinstreuer N, Paris M, Lehmann DM, Choksi N, Matheson J, Jacobs A, Lowit A, Allen D, Casey W (2018) Integrated decision strategies for skin sensitization hazard. J Appl Toxicol 38(3):432. https://doi.org/10.1002/jat.3572

Taylor KR, Yamasaki K, Radek KA, Di Nardo A, Goodarzi H, Golenbock D, Beutler B, Gallo RL (2007) Recognition of hyaluronan released in sterile injury involves a unique receptor complex dependent on Toll-like receptor 4, CD44, and MD-2. J Biol Chem 282(25):18265-18275. https://doi.org/10.1074/jbc.M6063 52200

Teunis M, Corsini E, Smits M, Madsen CB, Eltze T, Ezendam J, Galbiati V, Gremmer E, Krul C, Landin A, Landsiedel R, Pieters R, Rasmussen TF, Reinders J, Roggen E, Spiekstra S, Gibbs S (2013) Transfer of a two-tiered keratinocyte assay: IL-18 production by NCTC 2544 to determine the skin sensitizing capacity and epidermal equivalent assay to determine sensitizer potency. Toxicol In Vitro 27(3):1135-1150. https://doi.org/10.1016/j. tiv.2012.06.004

Toebak MJ, Gibbs S, Bruynzeel DP, Scheper RJ, Rustemeyer T (2009) Dendritic cells: biology of the skin. Contact Dermat 60(1):2-20. https://doi.org/10.1111/j.1600-0536.2008.01443.x

Try C, Moulari B, Béduneau A, Fantini O, Pin D, Pellequer Y, Lamprecht A (2016) Size dependent skin penetration of nanoparticles in murine and porcine dermatitis models. Eur J Pharm Biopharm 100:101-108. https://doi.org/10.1016/j.ejpb.2016.01.002

Tsuji RF, Szczepanik M, Kawikova I, Paliwal V, Campos RA, Itakura A, Akahira-Azuma M, Baumgarth N, Herzenberg LA, Askenase PW (2002) B cell-dependent T cell responses: IgM antibodies are required to elicit contact sensitivity. J Exp Med 196(10):12771290. https://doi.org/10.1084/jem.20020649

Tuschl H, Kovac R (2001) Langerhans cells and immature dendritic cells as model systems for screening of skin sensitizers. Toxicol In Vitro 15(4-5):327-331. https://doi.org/10.1016/S0887 -2333(01)00030-3

Tzellos TG, Sinopidis X, Kyrgidis A, Vahtsevanos K, Triaridis S, Printza A, Klagas I, Karakiulakis G, Papakonstantinou E (2011) Differential hyaluronan homeostasis and expression of proteoglycans in juvenile and adult human skin. J Dermatol Sci 61(1):6972. https://doi.org/10.1016/j.jdermsci.2010.10.010

Valadi H, Ekström K, Bossios A, Sjöstrand M, Lee JJ, Lötvall JO (2007) Exosome-mediated transfer of mRNAs and microRNAs is a novel mechanism of genetic exchange between cells. Nat Cell Biol 9(6):654-659. https://doi.org/10.1038/ncb1596

Vandebriel RJ, Van Och FM, van Loveren H (2005) In vitro assessment of sensitizing activity of low molecular weight compounds. Toxicol Appl Pharmacol 207(2 Suppl):142-148. https://doi. org/10.1016/j.taap.2005.01.054

Vennegaard MT, Bonefeld CM, Hagedorn PH, Bangsgaard N, Løvendorf MB, Odum N, Woetmann A, Geisler C, Skov L (2012) Allergic contact dermatitis induces upregulation of identical microRNAs in humans and mice. Contact Dermat 67(5):298305. https://doi.org/10.1111/j.1600-0536.2012.02083.x

Vocanson M, Hennino A, Rozières A, Poyet G, Nicolas JF (2009) Effector and regulatory mechanisms in allergic contact dermatitis. Allergy 64(12):1699-1714. https://doi.org/10.111 1/j.1398-9995.2009.02082.x von Blomberg-vander Flier BM, Scheper RJ (1990) In vitro tests with sensitized lymphocytes-relevance for predictive allergenicity testing. Toxicol In Vitro. 4(4-5):246-251

Wanner R, Sonnenburg A, Quatchadze M, Schreiner M, Peiser M, Zuberbier T, Stahlmann R (2010) Classification of sensitizing and irritative potential in a combined in-vitro assay. Toxicol Appl Pharmacol 245(2):211-218. https://doi.org/10.1016/j. taap.2010.02.019

Weber FC, Németh T, Csepregi JZ, Dudeck A, Roers A, Ozsvári B, Oswald E, Puskás LG, Jakob T, Mócsai A, Martin SF (2015) Neutrophils are required for both the sensitization and elicitation phase of contact hypersensitivity. J Exp Med 212(1):15-22. https ://doi.org/10.1084/jem.20130062

Weigel PH, Hascall VC, Tammi M (1997) Hyaluronan synthases. J Biol Chem 272(22):13997-14000. https://doi.org/10.1074/ jbc.272.22.13997

Weiss JM, Renkl AC, Maier CS, Kimmig M, Liaw L, Ahrens T, Kon S, Maeda M, Hotta H, Uede T, Simon (2001) Osteopontin is involved in the initiation of cutaneous contact hypersensitivity by inducing Langerhans and dendritic cell migration to lymph nodes. J Exp Med 194(9):1219-1229. https://doi.org/10.1084/ jem.194.9.1219

Weltzien HU, Moulon C, Martin S, Padovan E, Hartmann U, Kohler J (1996) T cell immune responses to haptens. Structural models for allergic and autoimmune reactions. Toxicology 107(2):141-151. https://doi.org/10.1016/0300-483X(95)03253-C

White SJ, Friedmann PS, Moss C, Simpson JM (1986) The effect of altering area of application and dose per unit area on sensitization to DNCB. Br J Dermatol 115:663-668. https://doi org/10.1111/j.1365-2133.1986.tb06646.x

Xu H, Dilulio NA, Fairchild RL (1996) T cell populations primed by hapten sensitization in contact sensitivity are distinguished by polarized patterns of cytokine production: interferon gammaproducing (Tc1) effector CD8 + T cells and interleukin (IL) 4/ IL-10-producing (Th2) negative regulatory CD4 + T cells. J Exp Med 183:1001-1012. https://doi.org/10.1084/jem.183.3.1001

Yamada Y, Itano N, Hata K, Ueda M, Kimata K (2004) Differential regulation by IL-1beta and EGF of expression of three different hyaluronan synthases in oral mucosal epithelial cells and fibroblasts and dermal fibroblasts: quantitative analysis using realtime RT-PCR. J Investig Dermatol 122(3):631-639. https://doi. org/10.1111/j.0022-202X.2004.22332.x

Yurchenco PD (2011) Basement membranes: cell scaffoldings and signaling platforms. Cold Spring Harb Perspect Biol 3(2):a004911. https://doi.org/10.1101/cshperspect.a004911

Zang Q, Paris M, Lehmann DM, Bell S, Kleinstreuer N, Allen D, Matheson J, Jacobs A, Casey W, Strickland J (2017) Prediction of skin sensitization potency using machine learning approaches. J Appl Toxicol 37(7):792-805. https://doi.org/10.1002/jat.3424

Zmolik JM, Mummert MEJ (2005) Pep-1 as a novel probe for the in situ detection of hyaluronan. Histochem Cytochem 53(6):745751. https://doi.org/10.1369/jhc.4A6491.2005

Zoeller JJ, Whitelock JM, Iozzo RV (2009) Perlecan regulates developmental angiogenesis by modulating the VEGF-VEGFR2 axis. Matrix Biol 28(5):284-291. https://doi.org/10.1016/j.matbi o.2009.04.010

Zug KA, Warshaw EM, Fowler JF Jr, Maibach HI, Belsito DL, Pratt MD et al (2009) Patch-test results of the North American Contact Dermatitis Group 2005-2006. Dermatitis 20:149-160. https:// doi.org/10.2310/6620.2009.08097 